\title{
Atmospheric nitrous acid (HONO) at a rural coastal site in North China: Seasonal variations and effects of biomass burning
}

\author{
Rongrong $\mathrm{Gu}^{\mathrm{a}, \mathrm{b}}$, Penggang Zheng ${ }^{\mathrm{a}}$, Tianshu Chen ${ }^{\mathrm{a}}$, Can Dong ${ }^{\mathrm{a}}$, Ya'nan Wang ${ }^{\mathrm{b}}$, Yiming Liu ${ }^{\mathrm{b}}$, \\ Yuhong Liu ${ }^{\mathrm{a}}$, Yuanyuan Luo ${ }^{\mathrm{a}}$, Guangxuan $\operatorname{Han}^{\mathrm{c}}$, Xinfeng Wang ${ }^{\mathrm{a}}$, Xuehua Zhou ${ }^{\mathrm{a}}$, Tao Wang ${ }^{\mathrm{b}}$, \\ Wenxing Wang ${ }^{a}$, Likun Xue ${ }^{\text {a,d,* }}$

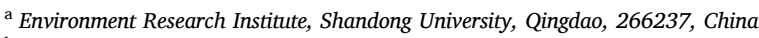 \\ ${ }^{\mathrm{b}}$ Department of Civil and Environmental Engineering, The Hong Kong Polytechnic University, Hong Kong, 99907, China \\ ${ }^{\mathrm{c}}$ Key Laboratory of Coastal Zone Environmental Processes and Ecological Remediation, Yantai Institute of Coastal Zone Research, Chinese Academy of Sciences, Yantai, \\ 264003, China \\ d Ji'nan Institute of Environmental Science, Ji'nan, 250100, China
}

\section{H I G H L I G H T S}

- Significant seasonal variations of HONO pollution and chemistry were found.

- Source strength of HONO can be enhanced by solar radiation and biomass burning.

- Biomass burning enhanced the role of aerosol in heterogeneous HONO formation.

\section{G R A P H I C A L A B S T R A C T}
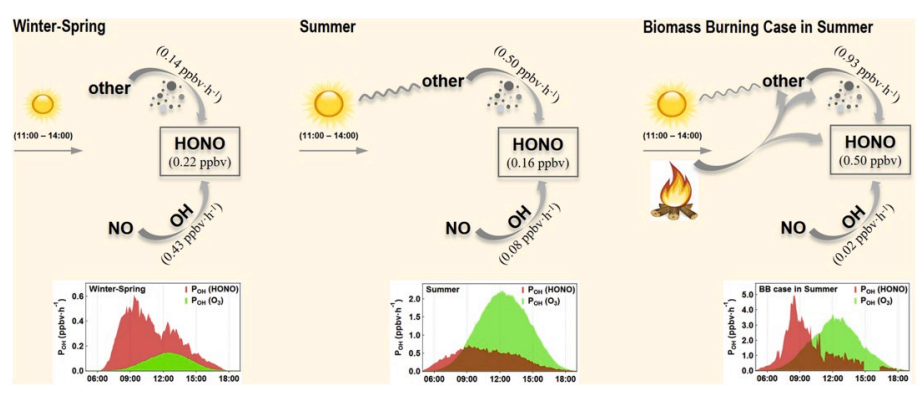

\begin{abstract}
A B S T R A C T
Nitrous acid (HONO) plays a significant role in atmospheric chemistry due to its contribution to hydroxyl radical $(\mathrm{OH})$. However, no scientific consensus has been achieved about the daytime HONO formation mechanisms. To identify the seasonal variations of HONO chemistry and the impacts of biomass burning (BB), we performed a twophased field study in winter-spring and summer (covering a harvest season) in 2017 at a rural coastal site in North China. Though the mean HONO concentration in winter-spring $(0.26 \pm 0.28 \mathrm{ppbv})$ was higher than in summer $(0.17$ $\pm 0.19 \mathrm{ppbv}$ ), the maximum HONO concentrations were comparable ( $\sim 2 \mathrm{ppbv})$ in the two campaigns. Both the $\mathrm{HONO} / \mathrm{NO}_{\mathrm{x}}$ ratio and nocturnal heterogeneous conversion efficiency of $\mathrm{HONO}\left(\mathrm{C}_{\mathrm{HONO}}\right)$ in summer were over twice of that in winter-spring. The daytime budget analysis also revealed that the strength of $\mathrm{P}_{\text {other }}$ (i.e., the HONO sources apart from the reaction of $\mathrm{OH}+\mathrm{NO}$ ) in summer was double of that in winter-spring. BB affected the HONO concentration by enhancing the contribution of heterogeneous HONO production on the aerosol surface but weakening the role of photo-related HONO formation. HONO photolysis was a significant source of $\mathrm{OH}$ in both winter-spring and summer, and its contribution could be further enhanced during the BB episode in summer. Our study demonstrates the significant seasonal variations of $\mathrm{HONO}$ and the effects of $\mathrm{BB}$, and suggests needs for more multiseason observations and considerations of $\mathrm{BB}$, especially during the harvest time, in HONO research.
\end{abstract}

\footnotetext{
* Corresponding author. Environment Research Institute, Shandong University, Qingdao, 266237, China.

E-mail address: xuelikun@sdu.edu.cn (L. Xue).
} 


\section{Introduction}

Atmospheric nitrous acid (HONO) has attracted great attention in recent decades due to its contribution to the hydroxyl radical $(\mathrm{OH})$ and participation in the $\mathrm{NO}_{\mathrm{x}}$ cycle (Lammel and Cape, 1996; Ren et al., 2003; Ye et al., 2016b). $\mathrm{OH}$ is the major atmospheric oxidant initiating the diurnal photochemistry that can affect air quality and climate (Finlayson-Pitts and Pitts, 2000). Numerous studies have shown that the photolysis of $\mathrm{HONO}$ can make a significant contribution to $\mathrm{OH}$ not only in the early morning but also throughout the rest of the day (Acker et al., 2006b; Fu et al., 2019). Therefore, investigating the pollution characteristics and chemistry of HONO is essential for a better understanding of atmospheric chemistry and the causes of regional air pollution.

Despite the relatively good understanding of the sinks (R1, R2, and dry deposition), sources of HONO are still under debate. Tropospheric HONO sources include chemical formation and direct emissions.

$\mathrm{HONO}+h \nu \rightarrow \mathrm{NO}+\mathrm{OH}(320 \mathrm{~nm}<\lambda<400 \mathrm{~nm})$

$\mathrm{HONO}+\mathrm{OH} \rightarrow \mathrm{NO}_{2}+\mathrm{H}_{2} \mathrm{O}$

The chemical reactions producing HONO include homogeneous gasphase reactions and heterogeneous reactions on various surfaces. So far, the proposed gas-phase reaction sources of HONO include reactions R3 to R7. Among them, R4 is of minor importance due to a low HONO yield (Sörgel et al., 2011; Ye et al., 2015). R5 is still under debate due to the unconfirmed reaction rate coefficient (Carr et al., 2009; Li et al., 2008). R6 is proposed to be a non-negligible HONO source in the urban atmosphere but should be verified through more laboratory studies (Bejan et al., 2006). R7 is only proposed by density functional theory calculations, and further experimental demonstrations are needed (Zhang and Tao, 2010). The proposed heterogeneous reactions producing HONO include reactions $\mathrm{R} 8$ to $\mathrm{R} 13$. $\mathrm{R} 8$ is the earliest identified heterogeneous source of HONO, but it generally produces insignificant HONO because of the small reaction rate constant (Finlayson-Pitts et al., 2003). R9 is the alternative reaction of $\mathrm{R} 8$ and is demonstrated to be an important HONO source, but its contribution has not been accurately quantified due to the complex influences of $\mathrm{NO}_{2}$ concentrations, moisture content, and surface characteristics on the $\mathrm{NO}_{2}$ uptake and HONO product yield (Finlayson-Pitts et al., 2003; Sakamaki et al., 1983). R10, the heterogeneous reactions of $\mathrm{NO}_{2}$ on the surfaces of reducing matters such as soot, humic acid, mineral dust, and other organic substrates, can produce HONO and the production rate has been proved to be photo-enhanced (Han et al., 2017; Monge et al., 2010; Stemmler et al., 2006). In R10, 'ads' means surface-adsorbed, and 'red' and 'ox' denote the reducing matters and oxidizing substances, respectively. $\mathrm{R} 11$ is proposed as a HONO source in an environment surrounding with $\mathrm{H}_{2} \mathrm{O}$ molecules but later believed to have little contribution to the ambient HONO (Kleffmann et al., 2004; Saliba et al., 2001). R12 is the photolysis and remobilization of $\mathrm{HNO}_{3}$ and nitrate on surfaces, and it has been recognized as the dominant HONO source in the low- $\mathrm{NO}_{\mathrm{x}}$ situation near the ground surface in daylight (Yang et al., 2018; Ye et al., 2016a; Zhou et al., 2003). Besides, the photolysis of particulate nitrate (R13) has been proposed to be a HONO source with the photolysis frequency ranging from $10^{-6}$ to $10^{-4}$ $\mathrm{s}^{-1}$, which is affected by nitrate loading, organic matters, aerosol $\mathrm{pH}$, and relative humidity (Ye et al., 2017; Gen et al., 2019).

$\mathrm{OH}+\mathrm{NO}+\mathrm{M} \rightarrow \mathrm{HONO}+\mathrm{M}$

$\mathrm{HO}_{2} \cdot \mathrm{H}_{2} \mathrm{O}+\mathrm{NO}_{2} \rightarrow \mathrm{HONO}+\mathrm{O}_{2}+\mathrm{H}_{2} \mathrm{O}$

$\mathrm{NO}_{2}^{*}+\mathrm{H}_{2} \mathrm{O} \rightarrow \mathrm{HONO}+\mathrm{OH}$

ortho - nitrophenol $+h \nu \rightarrow$ HONO

$2 \mathrm{NO}_{2}(\mathrm{~g})+\mathrm{H}_{2} \mathrm{O}(\mathrm{g})+\mathrm{NH}_{3}(\mathrm{~g}) \rightarrow \mathrm{HONO}(\mathrm{g})+\mathrm{NH}_{4} \mathrm{NO}_{3}(\mathrm{~s})$

$$
\begin{aligned}
& \mathrm{NO}+\mathrm{NO}_{2}+\mathrm{H}_{2} \mathrm{O} \stackrel{\text { surface }}{\rightarrow} 2 \mathrm{HONO} \\
& 2 \mathrm{NO}_{2}+\mathrm{H}_{2} \mathrm{O} \stackrel{\text { surface }}{\rightarrow} \mathrm{HONO}+\mathrm{HNO}_{3} \\
& \mathrm{NO}_{2}+\mathrm{red}_{(\mathrm{ads})} \rightarrow \mathrm{HONO}+\mathrm{ox}_{(\mathrm{ads})} \\
& \mathrm{HNO}_{3(\text { ads })}+\mathrm{NO}_{(\mathrm{g})} \rightarrow \mathrm{HONO}+\mathrm{NO}_{2} \\
& \mathrm{HNO}_{3(\text { ads })} / \text { nitrate }_{(\mathrm{ads})}+h \nu \rightarrow \mathrm{HONO} \\
& \mathrm{pNO}_{3}+h \nu \rightarrow \mathrm{HONO}+\mathrm{NO}_{2}
\end{aligned}
$$

Direct emission sources of HONO include fossil fuel combustion (Liu et al., 2017), microbial activities in soil (Oswald et al., 2013), and biomass burning (BB) (Burling et al., 2010). While fossil fuel combustion such as vehicle exhaust is a non-negligible HONO source in urban areas (Liang et al., 2017; Yun et al., 2017), soil emissions can make a considerable contribution to ambient HONO in the areas that retain a soil cover (Oswald et al., 2013; Zhang et al., 2016). Besides, both laboratory and field studies have shown that BB could emit HONO directly and produce $\mathrm{HONO}$ indirectly through heterogeneous reactions of $\mathrm{NO}_{2}$ on soot particles (Burling et al., 2010; Yokelson et al., 2009). In a field study, direct $\mathrm{BB}$ emission was estimated to contribute up to $17 \%$ to the observed $\mathrm{HONO}$, and heterogeneous conversion of $\mathrm{NO}_{2}$ contributed over $80 \%$ in a nighttime BB plume (Nie et al., 2015). Despite being a significant HONO source during the harvest seasons, the BB emission of HONO has been relatively less studied so far.

In recent decades, numerous HONO field studies have been conducted around the world. Most of the observations were short-term and mono-season, and only a few long-term or multi-season measurements have been carried out. Wang et al. (2013) observed weak seasonal variations of $\mathrm{HONO}$ and $\mathrm{HONO} / \mathrm{NO}_{2}$ at an urban site in Shanghai, China. In contrast, significant monthly and seasonal differences of HONO and $\mathrm{HONO} / \mathrm{NO}_{2}$ were observed in some other regions. Xu et al. (2015) and Li et al. (2018) reported the maximum HONO concentrations in winter and elevated $\mathrm{HONO} / \mathrm{NO}_{2}$ ratio in summer at an urban site in the Pearl River Delta (PRD) and the North China Plain (NCP), respectively. In comparison, the highest HONO concentration was observed in autumn with the lowest in winter at an urban site in Beijing (Wang et al., 2017). In view of the diverse temporal variations of HONO, more multi-season field studies are needed for the comprehensive understanding of HONO pollution, sources, and impacts on regional air quality.

To investigate the seasonal variations of HONO and the influence of $\mathrm{BB}$, we carried out a two-phased field study during the winter-spring and summer (covering a harvest season) in 2017 at a rural coastal site in the Yellow River Delta (YelRD) in North China. This site is located in the warm temperate monsoon zone with four distinct seasons and limited anthropogenic activities. We present the results to show the significant seasonal variations of HONO pollution characteristics, nocturnal heterogeneous conversion coefficient $\left(\mathrm{C}_{\mathrm{HONO}}\right)$, diurnal sources and sinks, and impacts on atmospheric oxidation capacity. We also analyze BB cases to highlight its important contribution to HONO during the harvest time.

\section{Experiments}

\subsection{Study site}

The field study was carried out at the Yellow River Delta Ecology Research Station of Coastal Wetland, Chinese Academy of Science $\left(118.98^{\circ} \mathrm{E}, 37.76^{\circ} \mathrm{N}\right)$, which is located in the YelRD region in North China (see Fig. 1). The station is surrounded by wide-open land with limited population or industrial activities within a radius of $10 \mathrm{~km}$. The three closest populated areas are a town $15 \mathrm{~km}$ southwest, a town $20 \mathrm{~km}$ northwest, and a town $23 \mathrm{~km}$ north-northwest with resident populations 
of about $23,000,46,000$, and 46,000 , respectively. The nearest city of Dongying is about $40 \mathrm{~km}$ southwest, with a population of over two million. Besides, the site is $45 \mathrm{~km}$ to the northeast of the Shengli Oilfield and $15 \mathrm{~km}$ to the southwest of the Gudong Oilfield. As the North China Plain is a major winter-wheat growing area, the air quality in this site may be affected by the wheat straw burning during the harvest season in June (Yin et al., 2019). To sum up, the station is characterized as a typical rural coastal site with distinct seasons and limited local anthropogenic emissions, but could be influenced by potential complicated transported regional air masses. More descriptions of this site were given by Zhang et al. (2019) and Zheng et al. (2019).

\subsection{Measurements}

The two-phased field study was performed in the winter-spring (from February 8th to March 24th) and summer (from June 1st to July 10th) of 2017. The instruments were housed in an air-conditioned container, and the sampling inlets were mounted on the roof-top of the container, which was about $3 \mathrm{~m}$ above the ground.

HONO was measured by an online commercial LOng Path Absorption Photometry instrument (LOPAP-03, QUMA, Germany) using photometric detection method (Heland et al., 2001). The collection efficiency was more than $99 \%$, and the detection limit was 5 pptv at a time resolution of $30 \mathrm{~s}$. Instrument background signals were automatically detected by sampling high purity nitrogen for 30 min every $12 \mathrm{~h}$. Single-point calibrations were carried out using diluted $\mathrm{NO}_{2}^{-}$standard (Nitrite Standard for IC, $1000 \mathrm{mg} / \mathrm{L}$, Sigma-Aldrich) at a time interval of 4 days. $\mathrm{NO}$ and $\mathrm{NO}_{\mathrm{y}}$ were detected with a commercial chemiluminescence analyzer (T-API Model T200U, USA), which was equipped with an externally-mounted molybdenum oxide converter. $\mathrm{NO}_{2}$ was measured with a Cavity Attenuated Phase Shift (CAPS) detector operating as an optical absorption spectrometer (T-API Model T500U, USA). $\mathrm{O}_{3}$ was measured by a standard UV photometric detector (TEI Model 49C, USA). CO was detected using an IR absorption analyzer equipped with a gas filter correlation wheel (T-API Model T300U, USA). $\mathrm{PM}_{2.5}$ was measured using a synchronized hybrid ambient real-time particulate monitor (Thermo Scientific Model 5030 SHARP, USA). Meanwhile, $\mathrm{PM}_{2.5}$ samples were collected on the quartz filter membrane (08:00-19:30 for daytime samples and 20:00-07:30 for nighttime samples) using a medium volume sampler (TH-150, Tianhong, China). Inorganic water-soluble ions $\left(\mathrm{K}^{+}, \mathrm{NO}_{3}^{-}, \mathrm{NH}_{4}^{+}\right.$, etc.) in the $\mathrm{PM}_{2.5}$ samples were then analysed by an ion chromatography (ICs-90, Dionex, USA).
Photolysis frequencies of $\mathrm{HONO}, \mathrm{NO}_{2}$, and $\mathrm{O}_{3}\left(\mathrm{j}(\mathrm{HONO}), \mathrm{j}\left(\mathrm{NO}_{2}\right)\right.$, and $\mathrm{j}$ $\left(\mathrm{O}^{1} \mathrm{D}\right)$ ) were measured with a spectro radiometer (Metcon, $\mathrm{GmbH}$, Germany). Meteorological parameters (temperature, relative humidity $(\mathrm{RH})$, and wind direction and speed) were monitored by a portable meteorological station (PC4, China). The time resolution of all the measurements above was $1 \mathrm{~min}$ except for $\mathrm{HONO}$ at $30 \mathrm{~s}$, meteorological parameters at $5 \mathrm{~min}, \mathrm{PM}_{2.5}$ at $30 \mathrm{~min}$, and water-soluble ions in fine particles at $12 \mathrm{~h}$. More details about their detection limits, precisions, and quality assurance and quality control procedures were provided by Xue et al. (2016) and Zhang et al. (2019).

\section{Results and discussion}

\subsection{Seasonal and diurnal variations}

Fig. 2 presents the overview of the observed HONO, related species and meteorological parameters, and the calculated $\mathrm{OH}$ throughout the two-phased field study. The $\mathrm{OH}$ concentration $([\mathrm{OH}])$ was calculated using equation (E1) with measured $\mathrm{j}\left(\mathrm{O}^{1} \mathrm{D}\right)$ and the coefficients of $\mathrm{a}=$ $2.4 \times 10^{6} \mathrm{~cm}^{-3}, \mathrm{~b}=1, \mathrm{c}=0.13 \times 10^{6} \mathrm{~cm}^{-3}$, which were proposed by Rohrer and Berresheim (2006) for rural areas. The calculated OH concentrations match well with the simulated results by the MCM model (Zhang et al., 2019). The descriptive statistics of $\mathrm{NO}, \mathrm{NO}_{2}, \mathrm{NO}_{\mathrm{y}}$, $\mathrm{HONO}$, temperature, and RH are listed in Table 1.

$$
[\mathrm{OH}]=\mathrm{a} \times\left(\mathrm{j}\left(\mathrm{O}^{1} \mathrm{D}\right) / 10^{-5} \mathrm{~s}^{-1}\right)^{\mathrm{b}}+\mathrm{c}
$$

Generally, concentrations of air pollutants (except for $\mathrm{O}_{3}$ and $\mathrm{K}^{+}$in fine particles) were higher in winter-spring than in summer. The average HONO concentrations were $0.26 \pm 0.28 \mathrm{ppbv}$ in winter-spring and 0.17 $\pm 0.20 \mathrm{ppbv}$ in summer, with the maximum values of 2.07 and 2.00 ppbv, respectively. The mean HONO concentration at this rural coastal site was lower than that in other polluted rural sites in the Yangtze River Delta (YRD) (Nie et al., 2015), PRD (Li et al., 2012), and Beijing-Tianjin-Hebei region (Yang et al., 2014) in China. However, it was much higher than that in most European sites (Acker et al., 2006a; Alicke et al., 2002; Meusel et al., 2016). $\mathrm{NO}_{\mathrm{x}}$ and $\mathrm{NO}_{\mathrm{y}}$, which are significant precursors of HONO, showed the mixing ratios ranging from several to tens of ppbv with much higher concentrations in winter-spring than in summer. $\mathrm{PM}_{2.5}$ also showed a similar seasonal variation pattern with $\mathrm{NO}_{\mathrm{x}}$ and $\mathrm{NO}_{\mathrm{y}}$. As a tracer of biomass burning, $\mathrm{K}^{+}$in fine particles showed elevated concentrations in two episodes during June 16-17 and June $29-30$ in summer with the daily average mixing ratio of more than

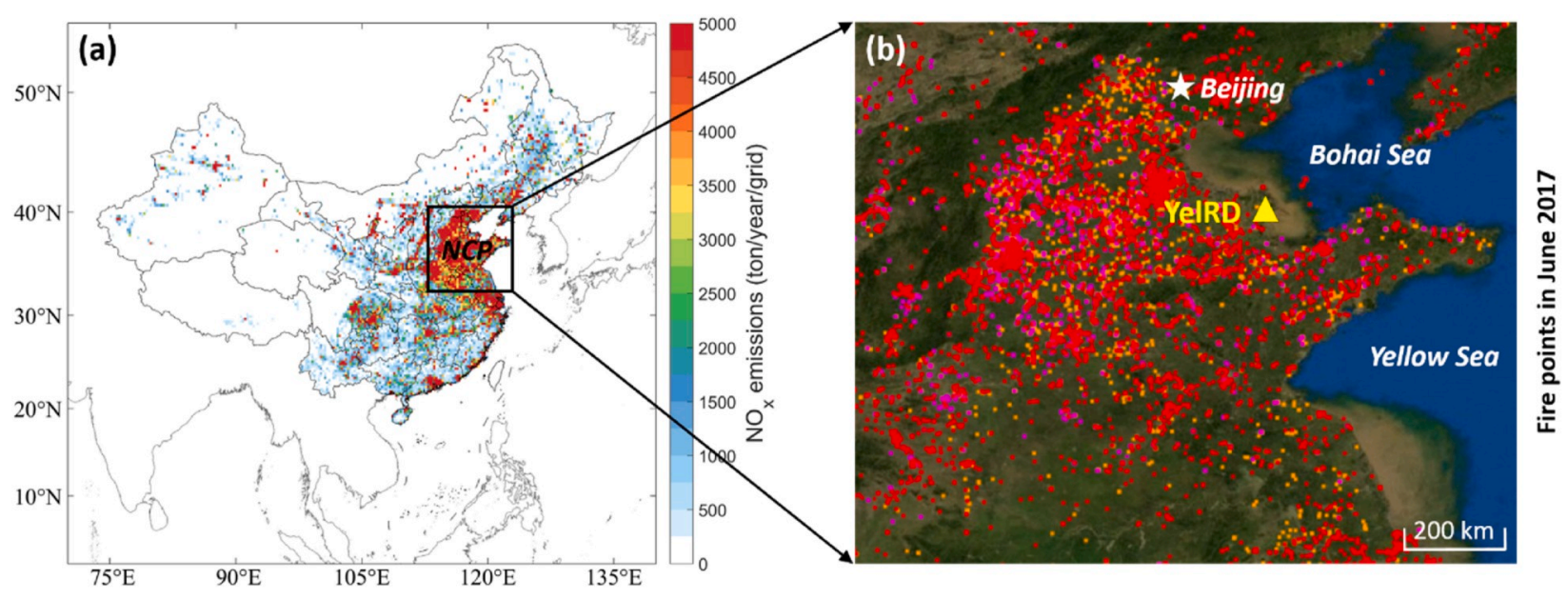

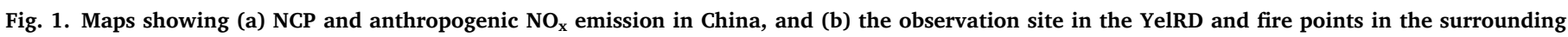

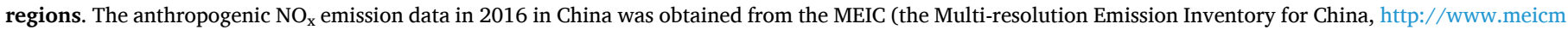

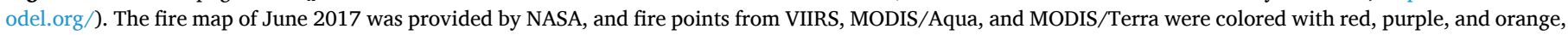

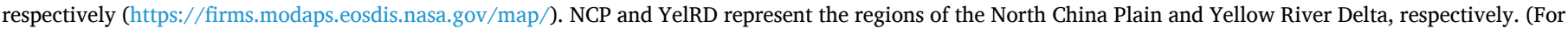
interpretation of the references to color in this figure legend, the reader is referred to the Web version of this article.) 


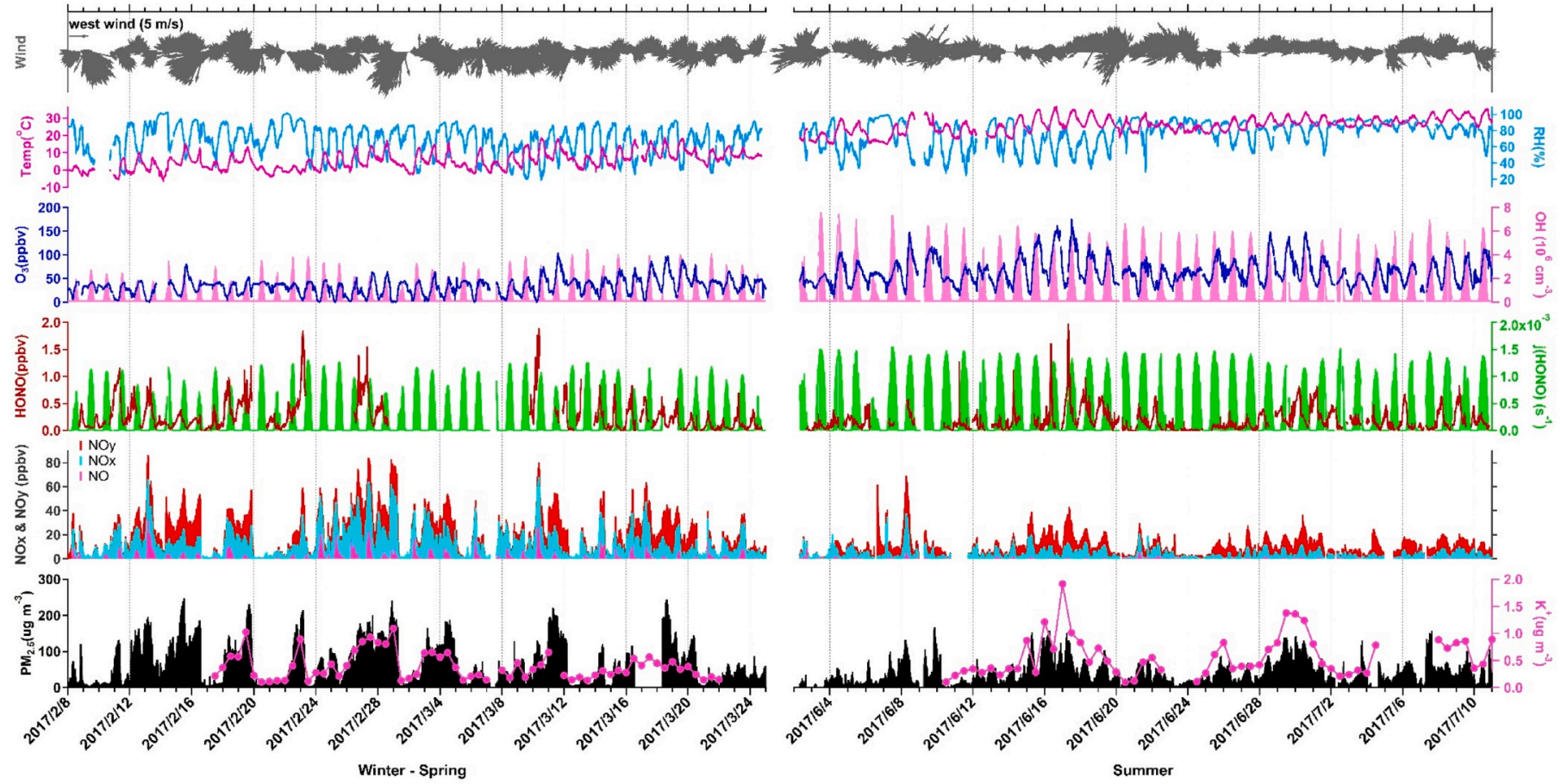

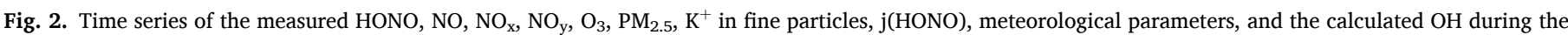
two-phased field study in winter-spring and summer.

Table 1

Statistics of the measured $\mathrm{HONO}, \mathrm{NO}, \mathrm{NO}_{2}, \mathrm{NO}_{\mathrm{y}}$, and meteorological parameters during winter-spring and summer.

\begin{tabular}{|c|c|c|c|c|c|c|c|c|c|c|c|c|}
\hline & \multicolumn{6}{|c|}{ Winter-Spring } & \multicolumn{6}{|c|}{ Summer } \\
\hline & \multirow[t]{2}{*}{ Min. } & \multirow[t]{2}{*}{ Max. } & \multirow[t]{2}{*}{ Med. } & \multicolumn{3}{|l|}{ Mean \pm SD } & \multirow[t]{2}{*}{ Min. } & \multirow[t]{2}{*}{ Max. } & \multirow[t]{2}{*}{ Med. } & \multicolumn{3}{|l|}{ Mean \pm SD } \\
\hline & & & & All Day & Daytime & Nighttime & & & & All Day & Daytime & Nighttime \\
\hline HONO (ppbv) & BDL & 2.07 & 0.18 & $0.26 \pm 0.28$ & $0.22 \pm 0.24$ & $0.30 \pm 0.28$ & BDL & 2.00 & 0.11 & $0.17 \pm 0.20$ & $0.16 \pm 0.20$ & $0.20 \pm 0.18$ \\
\hline NO (ppbv) & BDL & 46.92 & 0.17 & $1.49 \pm 3.28$ & $2.91 \pm 3.71$ & $0.33 \pm 1.95$ & BDL & 19.03 & 0.17 & $0.32 \pm 0.50$ & $0.43 \pm 0.61$ & $0.16 \pm 0.20$ \\
\hline $\mathrm{NO}_{2}$ (ppbv) & 0.32 & 55.34 & 7.86 & $10.41 \pm 9.11$ & $9.85 \pm 8.10$ & $10.50 \pm 9.70$ & BDL & 37.32 & 2.37 & $3.47 \pm 3.34$ & $3.41 \pm 3.68$ & $3.48 \pm 2.64$ \\
\hline $\mathrm{NO}_{\mathrm{y}}(\mathrm{ppbv})$ & BDL & 86.74 & 17.47 & $20.36 \pm 17.07$ & $22.55 \pm 17.90$ & $18.47 \pm 16.35$ & BDL & 69.58 & 8.45 & $10.14 \pm 7.73$ & $11.22 \pm 8.74$ & $8.45 \pm 5.42$ \\
\hline Temp. $\left({ }^{\circ} \mathrm{C}\right)$ & -6.4 & 18.6 & 4.9 & $5.3 \pm 4.9$ & $8.3 \pm 4.8$ & $3.0 \pm 3.7$ & 14.9 & 36.8 & 26.1 & $25.9 \pm 4.5$ & $27.3 \pm 4.5$ & $23.9 \pm 3.8$ \\
\hline RH (\%) & 19 & 102 & 72 & $68 \pm 18$ & $55 \pm 18$ & $79 \pm 11$ & 25 & 99 & 82 & $76 \pm 16$ & $71 \pm 17$ & $85 \pm 10$ \\
\hline
\end{tabular}

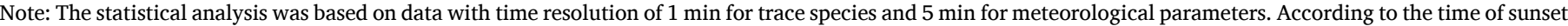

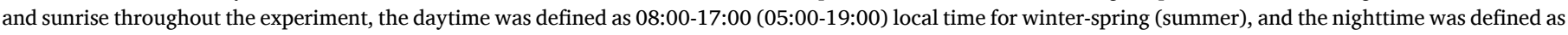
19:00-06:00 (20:00-04:00) local time for winter-spring (summer). BDL means below detection limit.

$1 \mu \mathrm{g} \cdot \mathrm{m}^{-3}$. As a secondary photochemical product, $\mathrm{O}_{3}$ exhibited typical high levels in summer with several peaks over $150 \mathrm{ppbv}$ as a result of enhanced photochemistry.

Fig. 3 shows the average diurnal patterns of HONO and related species and parameters during the two-phased field study. Most of the pollutants and parameters presented similar diurnal variations in the two campaigns except for $\mathrm{HONO} / \mathrm{NO}_{\mathrm{x}}$. $\mathrm{HONO}$ concentrations displayed a typical diurnal pattern in both campaigns, rising during the nighttime with a peak before sunrise and decreasing during the daytime with a valley around the late afternoon. The accumulation of HONO during nighttime indicated steady HONO sources at night. Given that the lifetime of HONO during midday was less than $30 \mathrm{~min}$, the considerable HONO concentrations during daytime suggested the existence of significant HONO sources. Besides, despite the greater HONO photolysis and several times lower concentrations of related pollutants $\left(\mathrm{NO}_{\mathrm{x}}, \mathrm{NO}_{\mathrm{y}}\right.$, and $\mathrm{PM}_{2.5}$ ) in summer than in winter-spring, the HONO concentrations in summer were just a little lower than those in winter-spring, indicating enhanced HONO sources in summer. The NO concentrations began to rise in the late night and peaked in the early morning during both campaigns, with a much sharper and wider peak in winter-spring than in summer. The diurnal patterns of $\mathrm{NO}_{2}, \mathrm{NO}_{\mathrm{y}}$, and $\mathrm{PM}_{2.5}$ were similar, peaking in the morning and then decreasing to the valley in the afternoon. $\mathrm{O}_{3}$ showed a typical diurnal pattern in both campaigns, increasing since sunrise and reaching the maximum at around 15:00 LT, and then decreasing until the next day before sunrise and reaching the minimum. The ratio of $\mathrm{HONO} / \mathrm{NO}_{\mathrm{x}}$ (or $\mathrm{HONO} / \mathrm{NO}_{2}$ ) has been used to characterize the heterogeneous formation of $\mathrm{HONO}$ from $\mathrm{NO}_{2}$ (e.g., Xu et al., 2015). As the $\mathrm{HONO} / \mathrm{NO}_{2}$ ratio may be subject to interferences from direct HONO emissions, the HONO/NO $\mathrm{Na}_{\mathrm{x}}$ ratio should be a more reliable parameter to indicate the efficiency of the heterogeneous $\mathrm{NO}_{2}$-to-HONO conversion. The diurnal pattern of $\mathrm{HONO} / \mathrm{NO}_{\mathrm{x}}$ displayed noticeable seasonal variations. In winter-spring, it decreased since late night and reached the minimum in the late afternoon, then increased rapidly before midnight and stayed stable for a few hours until the late night. In summer, an extra peak of $\mathrm{HONO} / \mathrm{NO}_{\mathrm{x}}$ showed up in the midday, which was comparable to the nighttime peak. This peculiar $\mathrm{HONO} / \mathrm{NO}_{\mathrm{x}}$ peak indicated some enhanced HONO sources at noon in summer. A detailed discussion about the potential HONO sources in the daytime will be given in section 3.3. 

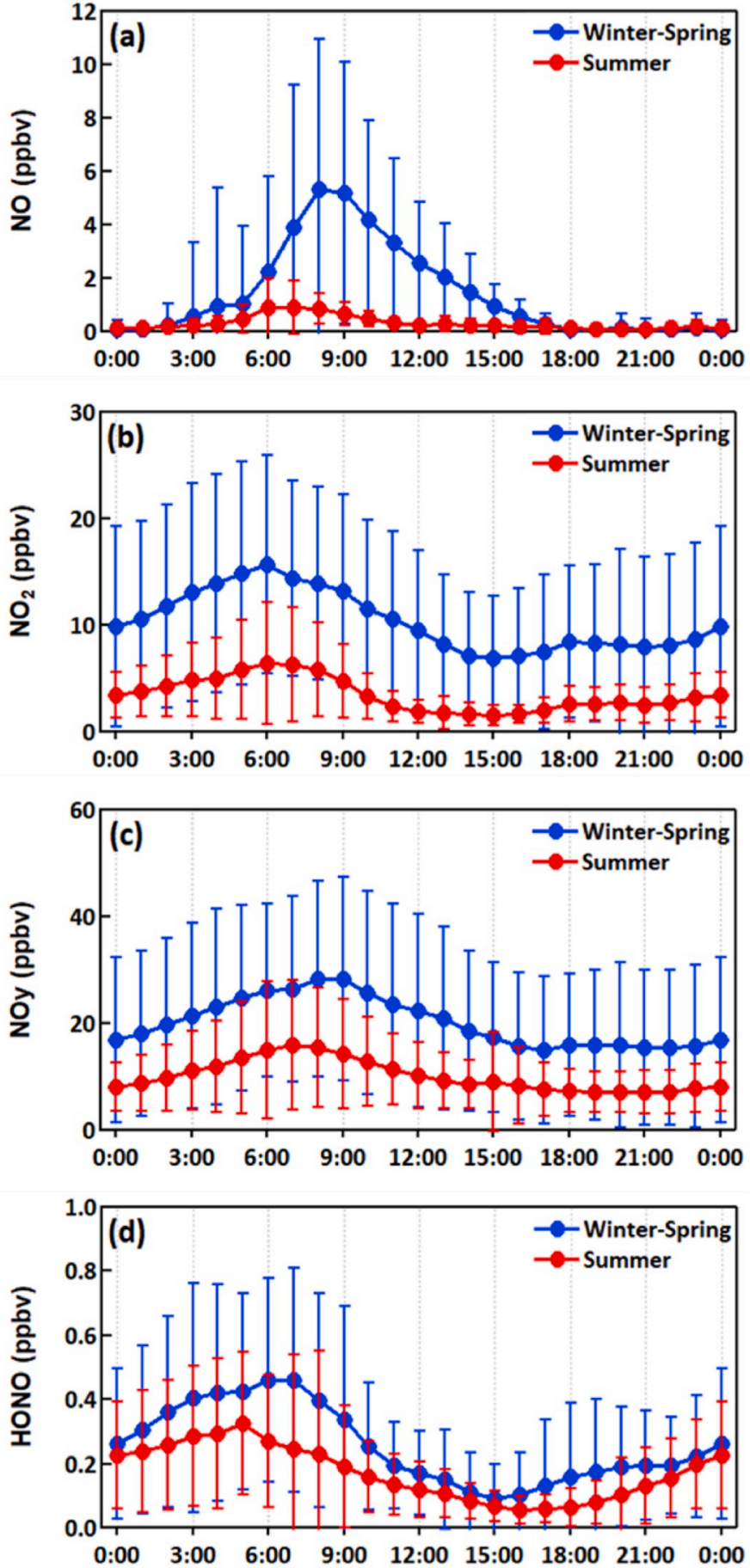
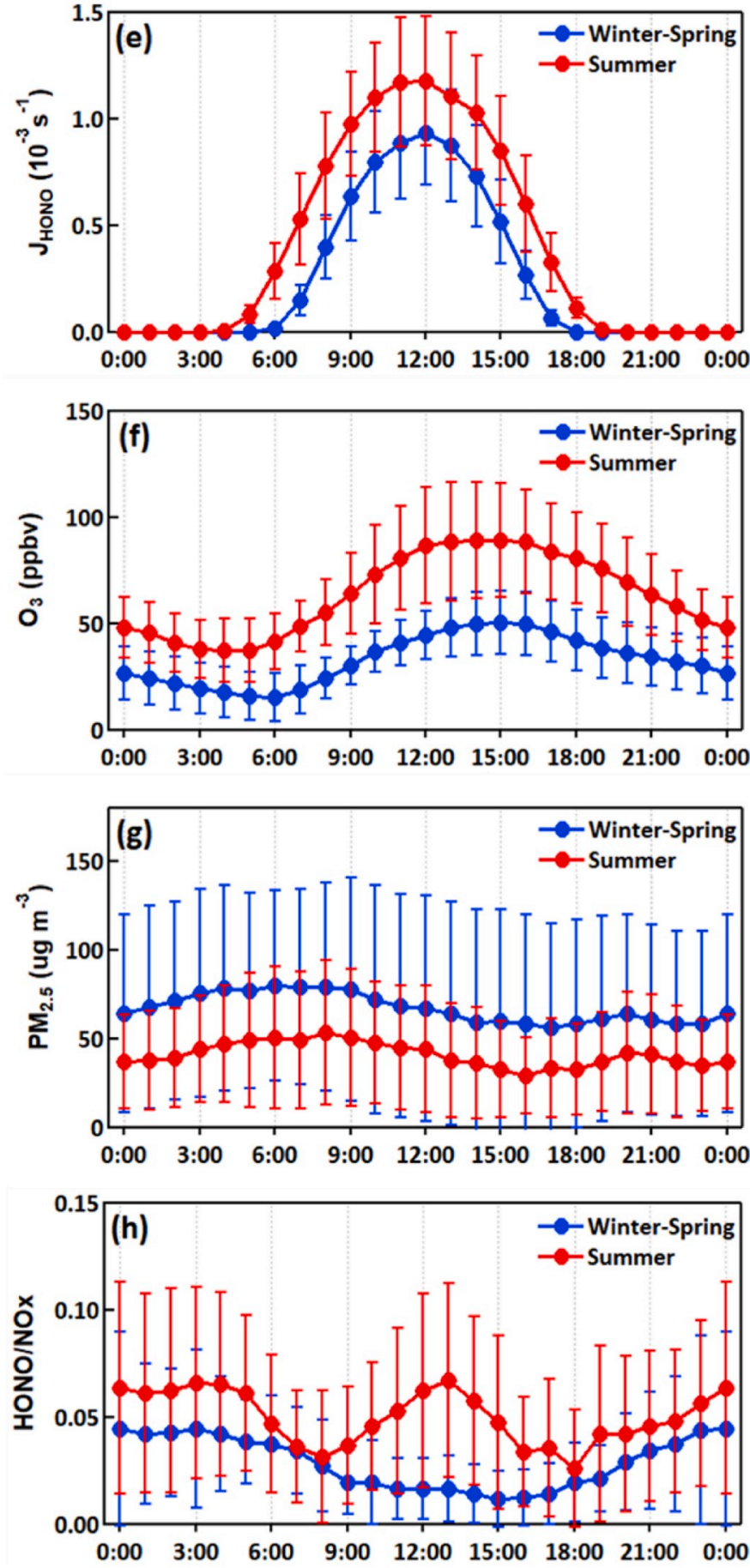

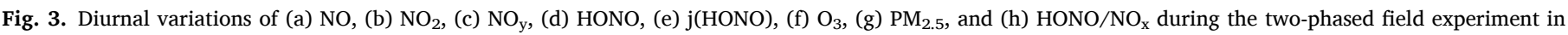
winter-spring and summer. The error bars represent one standard deviation.

\subsection{Nocturnal HONO formation}

Heterogeneous conversion of $\mathrm{NO}_{2}$ to $\mathrm{HONO}$ is the commonly accepted HONO source. The HONO conversion rate divided by $\mathrm{NO}_{2}$ $\left(\mathrm{C}_{\text {HONO}}, \mathrm{h}^{-1}\right)$ is a widely used scaling approach for the calculation of nocturnal $\mathrm{NO}_{2}$-to-HONO conversion frequency (Su et al., 2008a; Yu et al., 2009). Equation (E2), which is suitable for the $\mathrm{C}_{\mathrm{HONO}}$ calculation at rural sites with little or negligible effects of vehicle emissions, is used in this study (Su et al., 2008a). In E2, $\mathrm{P}_{\mathrm{HONO}}$ is the HONO production rate with the unit of ppbv$\cdot \mathrm{h}^{-1},\left[\overline{\mathrm{NO}_{2}}\right]$ is the mean $\mathrm{NO}_{2}$ concentration during time $t_{1}$ to $t_{2},[\mathrm{HONO}]_{t_{1 / 2}}$ is the HONO concentration at time $t_{1}$ or $t_{2}$. To calculate the $\mathrm{C}_{\text {HONO}}$, several criteria were adopted for the case selection. First, only the nocturnal data were considered to avoid the complicated daytime sources and sinks of HONO. Note that the heterogeneous conversion of $\mathrm{NO}_{2}$ to $\mathrm{HONO}$ is the most commonly accepted HONO source at nighttime, when both anthropogenic emissions (in particular at such a rural site in this study) and the atmospheric photochemistry are in their minimum intensity. Second, both $\mathrm{HONO}$ concentration and $\mathrm{HONO} / \mathrm{NO}_{2}$ ratio presented increasing trends for a relatively long period (e.g., more than $2 \mathrm{~h}$ ). Third, the concentrations of other pollutants (such as NO, $\mathrm{NO}_{2}$, and $\mathrm{CO}$, etc.) were stable to ensure that the air mass was consistent. Last, the weather conditions were stable with steady wind direction and 
small wind speeds (e.g., $<3 \mathrm{~m} \cdot \mathrm{s}^{-1}$ ). According to the above criteria, 10 and 7 cases were chosen for the winter-spring and summer phases, respectively, as listed in Table S1.

$\mathrm{C}_{\mathrm{HONO}}=\frac{\mathrm{P}_{\mathrm{HONO}}}{\left[\overline{\mathrm{NO}_{2}}\right]}=\frac{[\mathrm{HONO}]_{\mathrm{t}_{2}}-[\mathrm{HONO}]_{\mathrm{t}_{1}}}{\left(\mathrm{t}_{2}-\mathrm{t}_{1}\right)\left[\overline{\mathrm{NO}_{2}}\right]}$

The calculated $\mathrm{C}_{\mathrm{HONO}}$ showed a significant variation between winterspring and summer. While $\mathrm{C}_{\mathrm{HONO}}$ ranged from 0.48 to $1.54 \% \mathrm{~h}^{-1}$ with an average of $0.96 \pm 0.33 \% \mathrm{~h}^{-1}$ in winter-spring, it varied from 0.90 to $4.06 \% \mathrm{~h}^{-1}$ with a mean of $2.47 \pm 0.98 \% \mathrm{~h}^{-1}$ in summer. $\mathrm{C}_{\text {HONO }}$ presented a strong correlation with ambient temperature $(\mathrm{r}=0.76)$ and a moderate relationship with $\mathrm{RH}(\mathrm{r}=0.57)$, which was consistent with the study of Wen et al. (2019) in a marine boundary layer. The average $\mathrm{C}_{\text {HONO }}$ at our site was within the range of $0.43-3.36 \% \mathrm{~h}^{-1}$ that determined from other studies around the world (Liu et al., 2019; Xu et al., 2015). Seasonal variation of $\mathrm{C}_{\text {HONO }}$ has also been found by Liu et al. (2019) at a suburban site in Nanjing in the subtropical zone with four distinct seasons.

\subsection{Daytime HONO formation}

To investigate the strength of the daytime HONO sources and their seasonal variations, we performed a budget analysis based on the description by equation (E3) (Liu et al., 2019; Su et al., 2008b). The HONO sources include direct emission from anthropogenic combustions $\left(\mathrm{P}_{\mathrm{emis}}\right)$, the well-accepted homogeneous formation from reaction R3 $\left(\mathrm{P}_{\mathrm{OH}+\mathrm{NO}}\right)$, and the remaining other sources $\left(\mathrm{P}_{\mathrm{other}}\right)$. The sinks of gaseous HONO contain the homogeneous reaction of $\mathrm{R} 2\left(\mathrm{~L}_{\mathrm{OH}+\mathrm{HONO}}\right)$, photolysis $\left(\mathrm{L}_{\text {phot }}\right)$, and dry deposition $\left(\mathrm{L}_{\mathrm{dep}}\right)$. In addition, vertical and horizontal transport $\left(\mathrm{F}_{\mathrm{V}}\right.$ and $\left.\mathrm{F}_{\mathrm{h}}\right)$ could affect the HONO budget as well. Assuming that no HONO was emitted from anthropogenic activity at this coastal site (considering little anthropogenic emission sources nearby) and the influence of transport was negligible (given the short lifetime of HONO during the daytime), equation (E4) could be derived from E3 for the calculation of $\mathrm{P}_{\mathrm{other}}$. In $\mathrm{E} 4, \mathrm{k}_{\mathrm{OH}+\mathrm{HONO}}$ denotes the reaction rate constant of reaction R2 with a value of $2.5 \times 10^{-12} \times \exp (260 / \mathrm{T})$ $\mathrm{cm}^{3} \cdot \mathrm{molecules}^{-1} \cdot \mathrm{s}^{-1}$ (Atkinson et al., 2004); $\mathrm{k}_{\mathrm{OH}+\mathrm{NO}}$ denotes the reaction rate constant of reaction $\mathrm{R} 3$ with a value of $7.4 \times 10^{-31} \times$ $(\mathrm{T} / 300)^{-2.4} \times\left[\mathrm{N}_{2}\right] \mathrm{cm}^{3} \cdot$ molecules $^{-1} \cdot \mathrm{s}^{-1}$ (Atkinson et al., 2004); $\nu_{\text {HONO }}$ is the dry deposition velocity of HONO in the daytime using an empirical value of $2 \mathrm{~cm} \cdot \mathrm{s}^{-1}$ (Harrison et al., 1996); $\mathrm{H}$ is the mixing height of HONO with an assumed value of $200 \mathrm{~m}$ (Alicke et al., 2002).

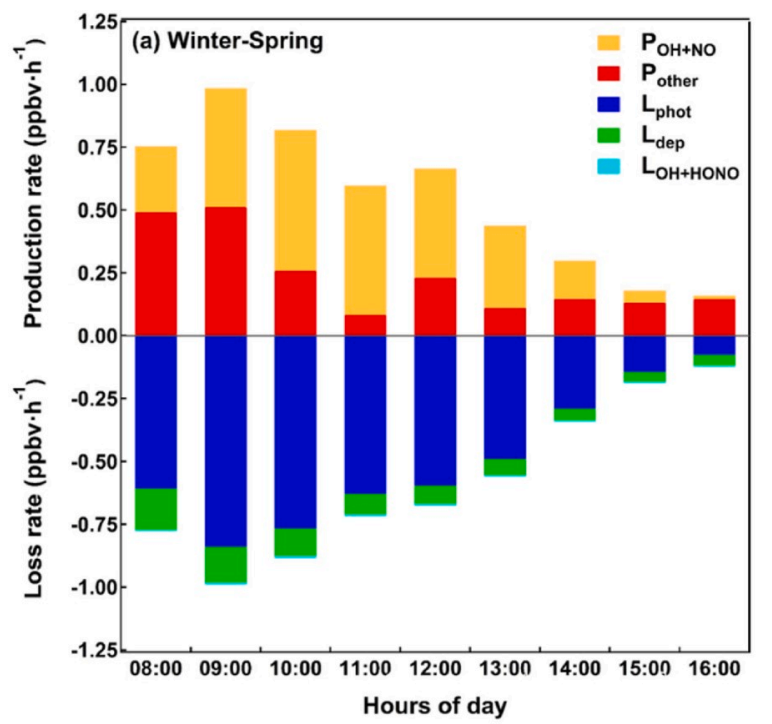

$$
\frac{\Delta[\mathrm{HONO}]}{\Delta \mathrm{t}}=\left(\mathrm{P}_{\mathrm{emis}}+\mathrm{P}_{\mathrm{OH}+\mathrm{NO}}+\mathrm{P}_{\text {other }}\right)-\left(\mathrm{L}_{\mathrm{OH}+\mathrm{HONO}}+\mathrm{L}_{\mathrm{phot}}+\mathrm{L}_{\mathrm{dep}}\right)+\mathrm{F}_{\mathrm{v}}+\mathrm{F}_{\mathrm{h}}
$$

$$
\begin{gathered}
\mathrm{P}_{\text {other }}=\mathrm{j}(\mathrm{HONO})[\mathrm{HONO}]+\mathrm{k}_{\mathrm{OH}+\mathrm{HONO}}[\mathrm{OH}][\mathrm{HONO}]+\frac{\Delta[\mathrm{HONO}]}{\Delta \mathrm{t}} \\
+\frac{\nu_{\mathrm{HONO}}}{\mathrm{H}}[\mathrm{HONO}]-\mathrm{k}_{\mathrm{OH}+\mathrm{NO}}[\mathrm{OH}][\mathrm{NO}]
\end{gathered}
$$

Fig. 4 shows the hourly average HONO budgets during the daytime in the winter-spring and summer campaigns. Seasonal consistencies of HONO sinks but significant seasonal differences of HONO sources were found. During both campaigns, HONO photolysis ( $\mathrm{L}_{\mathrm{phot}}$ ) was the major loss pathway, followed by dry deposition $\left(\mathrm{L}_{\mathrm{dep}}\right)$ and the negligible homogeneous reaction of $\mathrm{R} 2$ ( $\mathrm{L}_{\mathrm{OH}+\mathrm{HONO}}$ ). During noontime (11:00-14:00 LT) in winter-spring, the average loss rate of $\mathrm{L}_{\text {phot }}$, $\mathrm{L}_{\mathrm{dep}}$, and $\mathrm{L}_{\mathrm{OH}+\mathrm{HONO}}$ was $0.57,0.07$, and $0.01 \mathrm{ppbv} \cdot \mathrm{h}^{-1}$, respectively. During noontime in summer, in comparison, the average loss rate of $\mathrm{L}_{\text {phot }}, \mathrm{L}_{\mathrm{dep}}$, and $\mathrm{L}_{\mathrm{OH}+\mathrm{HONO}}$ was $0.53,0.04$, and $0.01 \mathrm{ppbv} \cdot \mathrm{h}^{-1}$, respectively. Despite the similar HONO sinks, the HONO sources presented significant differences between the two campaigns. In winter-spring, the homogeneous reaction of $\mathrm{R} 3\left(\mathrm{P}_{\mathrm{OH}+\mathrm{NO}}\right)$ was the dominant HONO source with a mean production rate of $0.43 \mathrm{ppbv} \cdot \mathrm{h}^{-1}$ during noontime, while $\mathrm{P}_{\text {other }}$ was 0.14 $\mathrm{ppbv} \cdot \mathrm{h}^{-1}$, accounting for $25 \%$ of the HONO production. During noontime in summer, however, the average production rate of $\mathrm{P}_{\mathrm{OH}+\mathrm{NO}}$ was only $0.08 \mathrm{ppbv} \cdot \mathrm{h}^{-1}$, whilst $\mathrm{P}_{\text {other }}$ was up to $0.50 \mathrm{ppbv} \cdot \mathrm{h}^{-1}$ and accounted for $87 \%$ of the HONO production. The strength of $\mathrm{P}_{\text {other }}$ during noontime at our site was at the lowest level compared with other studies, whose results ranged from 0.22 to $3.05 \mathrm{ppbv} \cdot \mathrm{h}^{-1}$ (see Liu et al. (2019) and references therein). The seasonal variation of $\mathrm{P}_{\text {other }}$ in this study was consistent with that at an urban site in Beijing, where the value in summer $\left(3.05 \mathrm{ppbv} \cdot \mathrm{h}^{-1}\right)$ was higher than that in spring $\left(2.63 \mathrm{ppbv} \cdot \mathrm{h}^{-1}\right)$ and winter (1.30 ppbv. $\mathrm{h}^{-1}$ ) (Wang et al., 2017). In comparison, it differed from that at a suburban site in Nanjing where higher values occurred in spring $\left(1.73 \mathrm{ppbv} \cdot \mathrm{h}^{-1}\right)$ and winter $\left(1.15 \mathrm{ppbv} \cdot \mathrm{h}^{-1}\right)$ than in summer (1.00 ppbv.h ${ }^{-1}$ ) (Liu et al., 2019). The varying seasonal differences of the HONO budget demonstrate that multi-season observations are required at diverse sites for HONO study.

The elevated strength and proportion of $\mathrm{P}_{\text {other }}$ in summer suggest the existence of some strongly enhanced HONO source(s) in the summer season. To investigate the potential daytime HONO sources, we summarized the correlations between the daytime (08:00-17:00 LT) $\mathrm{P}_{\text {other }}$ with relevant trace species and meteorological parameters (see Table 2).

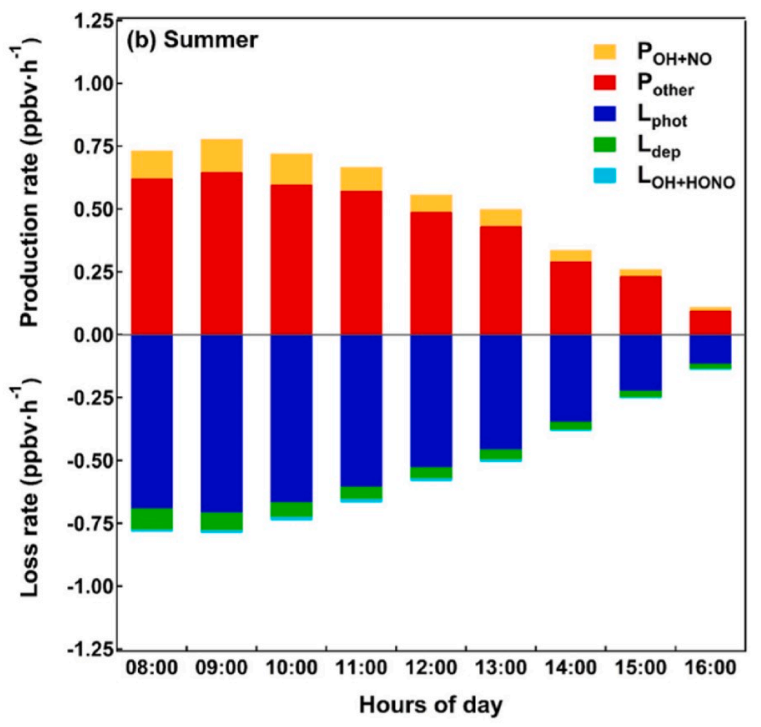

Fig. 4. Hourly average HONO production and loss rates during the daytime in (a) winter-spring and (b) summer. 
Table 2

Correlations of the diurnal $\mathrm{P}_{\text {other }}$ against related pollutants and parameters.

\begin{tabular}{|c|c|c|c|c|c|c|c|c|c|c|}
\hline \multirow[t]{2}{*}{ Parameter } & \multirow{2}{*}{$\frac{\text { Total }}{\mathrm{r}}$} & \multirow[b]{2}{*}{$\mathrm{N}$} & \multicolumn{2}{|c|}{ Winter-Spring } & \multicolumn{2}{|c|}{ Summer } & \multicolumn{2}{|c|}{$\mathrm{BB}$ case } & \multicolumn{2}{|c|}{ NBB case } \\
\hline & & & $\mathrm{r}$ & $\mathrm{N}$ & $\mathrm{r}$ & $\mathrm{N}$ & $\mathrm{r}$ & $\mathrm{N}$ & $\mathrm{r}$ & $\mathrm{N}$ \\
\hline RH & -0.04 & 989 & 0.06 & 455 & -0.24 & 534 & 0.88 & 29 & 0.08 & 19 \\
\hline $\mathrm{j}\left(\mathrm{NO}_{2}\right)$ & 0.24 & 1002 & -0.10 & 455 & 0.29 & 547 & -0.11 & 29 & 0.89 & 19 \\
\hline $\mathrm{CO}$ & 0.23 & 1001 & 0.25 & 454 & 0.39 & 547 & 0.08 & 29 & 0.73 & 19 \\
\hline $\mathrm{SO}_{2}$ & 0.22 & 1000 & 0.28 & 453 & 0.59 & 547 & 0.47 & 29 & 0.35 & 19 \\
\hline NO & 0.01 & 1002 & 0.19 & 455 & 0.09 & 547 & 0.74 & 29 & 0.63 & 19 \\
\hline $\mathrm{NO}_{2}$ & 0.05 & 1002 & 0.18 & 455 & 0.47 & 547 & 0.81 & 29 & 0.51 & 19 \\
\hline $\mathrm{NO}_{\mathrm{z}}$ & 0.17 & 1002 & -0.02 & 455 & 0.57 & 547 & 0.51 & 29 & 0.36 & 19 \\
\hline $\mathrm{PM}_{2.5}$ & 0.15 & 968 & 0.20 & 439 & 0.36 & 529 & 0.74 & 29 & 0.20 & 19 \\
\hline $\mathrm{PM}_{2.5} * \mathrm{NO}_{2}$ & 0.08 & 968 & 0.22 & 439 & 0.53 & 529 & 0.83 & 29 & 0.52 & 19 \\
\hline $\mathrm{PM}_{2.5} * \mathrm{NO}_{\mathrm{z}}$ & 0.11 & 968 & 0.10 & 439 & 0.54 & 529 & 0.64 & 29 & 0.30 & 19 \\
\hline $\mathrm{j}\left(\mathrm{NO}_{2}\right) * \mathrm{NO}_{2}$ & 0.09 & 1002 & 0.02 & 455 & 0.56 & 547 & 0.80 & 29 & 0.78 & 19 \\
\hline $\mathrm{j}\left(\mathrm{NO}_{2}\right) * \mathrm{NO}_{\mathrm{z}}$ & 0.30 & 1002 & -0.14 & 455 & 0.61 & 547 & 0.38 & 29 & 0.67 & 19 \\
\hline $\mathrm{j}\left(\mathrm{NO}_{2}\right) * \mathrm{PM}_{2.5}$ & 0.24 & 968 & 0.07 & 439 & 0.40 & 529 & 0.54 & 29 & 0.65 & 19 \\
\hline $\mathrm{j}\left(\mathrm{NO}_{2}\right) * \mathrm{NO}_{2} * \mathrm{PM}_{2.5}$ & 0.08 & 968 & 0.08 & 439 & 0.57 & 529 & 0.82 & 29 & 0.75 & 19 \\
\hline $\mathrm{j}\left(\mathrm{NO}_{2}\right) * \mathrm{NO}_{\mathrm{z}} * \mathrm{PM}_{2.5}$ & 0.18 & 968 & 0.00 & 439 & 0.56 & 529 & 0.58 & 29 & 0.51 & 19 \\
\hline
\end{tabular}

Note: The daytime period was set as 08:00-17:00 here following section 3.3. The time resolution of all the data used for the correlation calculation is 30 min.

(a) NBB case

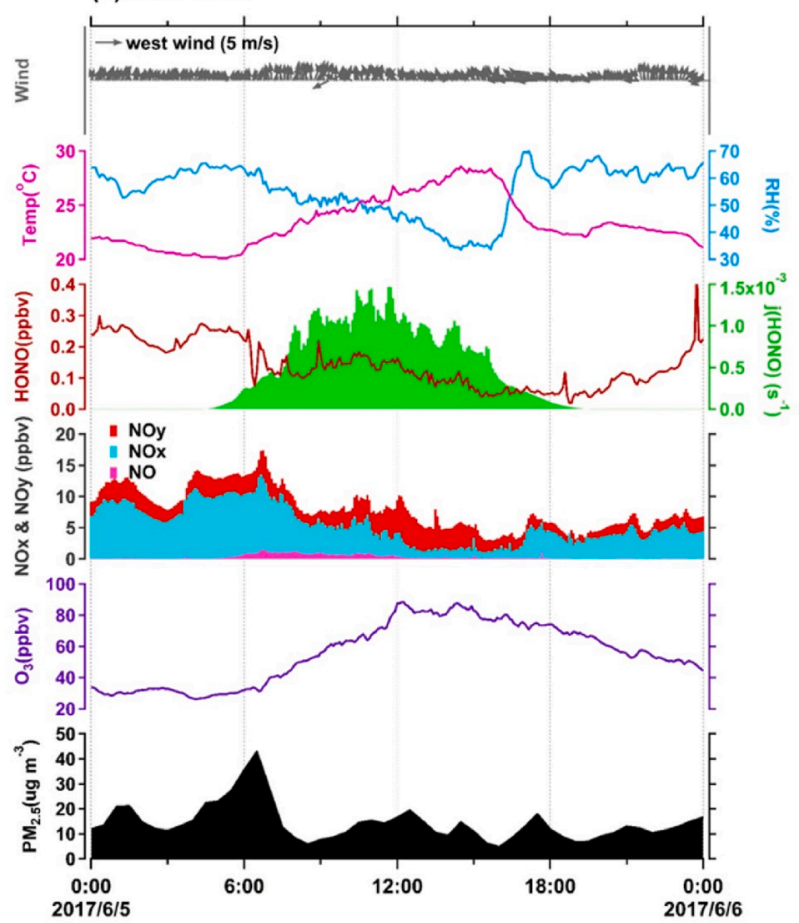

(b) BB case

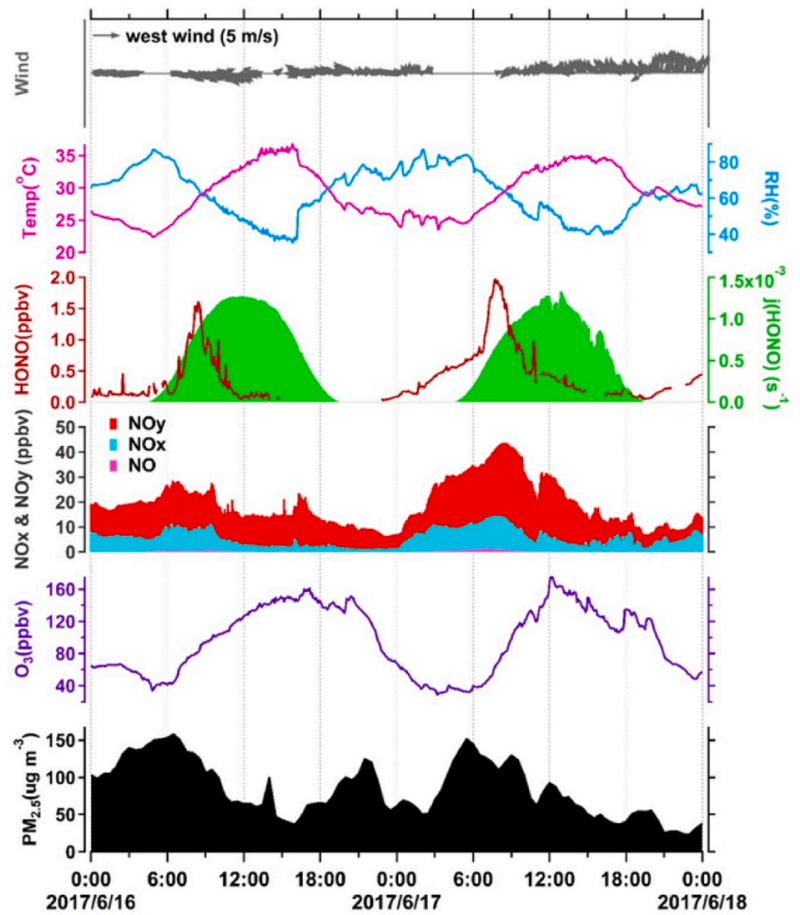

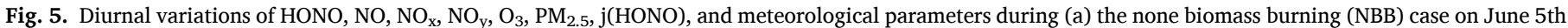
and (b) the biomass burning (BB) case from June 16th to 17th 2017.

The correlation analysis revealed different seasonal characteristics of the potential daytime HONO sources. In winter-spring, $\mathrm{P}_{\text {other }}$ showed no linear correlations with $\mathrm{j}\left(\mathrm{NO}_{2}\right)$-related parameters $(\mathrm{r} \leq 0.1)$, suggesting that the other HONO source in winter-spring had no relationship with the photo-related HONO formation mechanisms. And the weak positive correlations $(r<0.3)$ between $\mathrm{P}_{\text {other }}$ with other pollutants give no significant indications of any potential HONO source. In summer, direct emission sources were ruled out first because $\mathrm{P}_{\text {other }}$ showed no correlation with NO $(r=0.09)$, which is the tracer of fresh plume emitted by fuel combustion. Some studies have proposed that photo-enhanced heterogeneous reactions of $\mathrm{NO}_{2}$ and photolysis of nitrate and nitric acid may be important daytime HONO sources (Finlayson-Pitts et al., 2003; Zhou et al., 2003; Ye et al., 2016a). Here we examined the correlations of $\mathrm{P}_{\text {other }}$ with $\mathrm{NO}_{2}$ and $\mathrm{NO}_{\mathrm{z}}$, taking $\mathrm{NO}_{\mathrm{z}}$ as a proxy of nitrate and nitric acid (highly time resolved measurements of nitrate and nitric acid were unavailable in this study). $\mathrm{P}_{\text {other }}$ showed overall moderate correlations with $\mathrm{NO}_{2}(\mathrm{r}=0.47)$ and $\mathrm{NO}_{\mathrm{z}}(\mathrm{r}=0.57)$. When taking solar radiation $\left(\mathrm{j} \mathrm{NO}_{2}\right)$ as a proxy) into consideration, the correlations became stronger, with $\mathrm{j}\left(\mathrm{NO}_{2}\right) * \mathrm{NO}_{2}(\mathrm{r}=0.56)$ and $\mathrm{j}\left(\mathrm{NO}_{2}\right) * \mathrm{NO}_{\mathrm{z}}(\mathrm{r}=0.61)$. On one hand, the increased correlation indicates the photo-induced heterogeneous formation mechanism of HONO. On another hand, according to the correlation strength, it can be argued that the photolysis of nitrate and nitric acid as well as photo-enhanced heterogeneous conversion of $\mathrm{NO}_{2}$ should be important HONO sources in the YelRD region. These results agree with a recent study that demonstrated aqueous phase photolysis of particulate nitrate as an important source of HONO (Gen et al., 2019). 


\subsection{Effects of biomass burning}

As June is the harvest month of winter wheat in North China, deteriorated air quality could happen during this period due to the wheat straw burning. As shown in Fig. 2, highly elevated concentrations of HONO, $\mathrm{K}^{+}$in fine particles, $\mathrm{PM}_{2.5}$, and $\mathrm{NO}_{\mathrm{y}}$ were observed on June 16 th and 17th during which the daily fire maps (see Fig. S1 (https://firms. modaps.eosdis.nasa.gov)) displayed intensive fire points around North China. On June 5th, by contrast, almost no fire point was detected around our study site. Therefore, June 16th-17th was considered as the typical biomass burning (BB) case, and June 5th was considered as the none-biomass burning (NBB) case.

Significant differences in the pollution characteristics were found between the BB case and the NBB case. Fig. 5 presents the diurnal variations of $\mathrm{HONO}$ and several relevant pollutants and parameters during the two cases. The average HONO concentration was about three times higher in the BB case $(0.41 \pm 0.42 \mathrm{ppbv})$ than in the NBB case $(0.14 \pm$ $0.07 \mathrm{ppbv})$. In the NBB case, the maximum HONO concentration occurred in the late night and was about $0.45 \mathrm{ppbv}$. In the $\mathrm{BB}$ case, the HONO concentration increased unusually in the early morning, and the peak went across the whole morning with a substantially elevated maximum of $1.60 \mathrm{ppbv}$ on June 16th and $2.00 \mathrm{ppbv}$ on 17 th, which was also the maximum value observed throughout the summer campaign. While the average concentrations of $\mathrm{NO}_{\mathrm{x}}$ were the same in both cases (both of $5.4 \pm 3.1 \mathrm{ppbv}$ ), the average concentration of $\mathrm{NO}_{\mathrm{y}}$ was over two times higher in the BB case $(18.6 \pm 8.2 \mathrm{ppbv})$ than in the NBB case (8.0 $\pm 3.3 \mathrm{ppbv}$ ), indicating that the BB plume was much chemically aged than the NBB plume. The average concentration of $\mathrm{PM}_{2.5}$ in the $\mathrm{BB}$ case $\left(84.9 \pm 37.3 \mu \mathrm{g} \cdot \mathrm{m}^{-3}\right)$ was about six times higher than that in the NBB case $\left(14.2 \pm 7.3 \mu \mathrm{g} \cdot \mathrm{m}^{-3}\right)$, implying much heavier particulate pollution, and as detailed below, aerosol played a more important role in the heterogeneous formation of $\mathrm{HONO}$ during the $\mathrm{BB}$ case. The $\mathrm{O}_{3}$ concentration doubled in the BB case ( $96 \pm 42 \mathrm{ppbv})$, indicating more serious photochemistry pollution.

The strength of the other HONO sources $\left(\mathrm{P}_{\text {other }}\right)$, as shown in Fig. S2, increased substantially in the BB case. To explore the potential HONO source and the influence of BB on HONO chemistry during this episode, Table 2 lists the correlations of $\mathrm{P}_{\text {other }}$ against various pollutants and parameters in the BB and NBB cases. In both cases, differing from the whole summer campaign, $\mathrm{P}_{\text {other }}$ presented moderate correlations with $\mathrm{NO}$, indicating a considerable contribution of direct HONO emissions. In the NBB case, $\mathrm{P}_{\text {other }}$ was highly correlated with $\mathrm{j}\left(\mathrm{NO}_{2}\right)$, and all the correlations with $\mathrm{NO}_{2}, \mathrm{NO}_{\mathrm{z}}$, and $\mathrm{PM}_{2.5}$ increased significantly after considering the solar radiation effect. In the $\mathrm{BB}$ case, however, no correlation of $\mathrm{P}_{\text {other }}$ with $\mathrm{j}\left(\mathrm{NO}_{2}\right)$ was found, and all the relationships with $\mathrm{NO}_{2}, \mathrm{NO}_{\mathrm{z}}$, and $\mathrm{PM}_{2.5}$ weakened more or less when considering the solar radiation. This phenomenon implies that the role of the photo-related heterogeneous formation mechanism of HONO was suppressed during the BB period, which should be ascribed to the dimming effect of high aerosol loading from BB emissions. Compared with the NBB case, the correlation of $\mathrm{P}_{\text {other }}$ with $\mathrm{PM}_{2.5}$ drastically enhanced in the $\mathrm{BB}$ case, implying significantly increased effects of particles. As the indicator of particle loading, $\mathrm{PM}_{2.5}$ could contribute to HONO chemistry through either producing HONO via the photolysis of particulate nitrate or providing the aerosol surface for HONO heterogeneous formation. Because of the weaker relationship of $\mathrm{P}_{\text {other }}$ with $\mathrm{j}\left(\mathrm{NO}_{2}\right) * \mathrm{PM}_{2.5}$ compared with $\mathrm{PM}_{2.5}$, and the stronger correlation of $\mathrm{P}_{\text {other }}$ with $\mathrm{PM}_{2.5} * \mathrm{NO}_{2}$ (or $\mathrm{PM}_{2.5} * \mathrm{NO}_{\mathrm{z}}$ ) compared with $\mathrm{NO}_{2}$ ( or $\mathrm{NO}_{\mathrm{z}}$ ), we argue that particles may play a major role in HONO formation by providing heterogeneous reaction surface during the BB episode. It should be noted that such correlation analysis may be inherently subject to some uncertainties, and more detailed process studies are needed to better understand the HONO formation mechanisms in the BB plumes.

\subsection{Contribution to the $\mathrm{OH}$ source}

Photolysis of HONO can make a considerable contribution to the $\mathrm{OH}$ radical during the daytime. To evaluate the net $\mathrm{OH}$ production rate from HONO photolysis, equation (E5) was used for the calculation considering the homogeneous reactions of $\mathrm{R} 1$ to R3. For comparison, the $\mathrm{OH}$ production rate from the photolysis of $\mathrm{O}_{3}$, another significant precursor of $\mathrm{OH}$, was calculated using equation (E6) based on the reactions of R14 to $\mathrm{R} 16 . \mathrm{P}_{\mathrm{OH}}(\mathrm{HONO})$ is the net $\mathrm{OH}$ production rate from HONO photolysis, and $\mathrm{P}_{\mathrm{OH}}\left(\mathrm{O}_{3}\right)$ is the $\mathrm{OH}$ production rate from $\mathrm{O}_{3}$ photolysis. The reaction rate constants were taken from Atkinson et al. (2004).

$\mathrm{O}_{3}+h \nu \rightarrow \mathrm{O}\left({ }^{1} \mathrm{D}\right)+\mathrm{O}_{2} \quad(\lambda<340 \mathrm{~nm})$
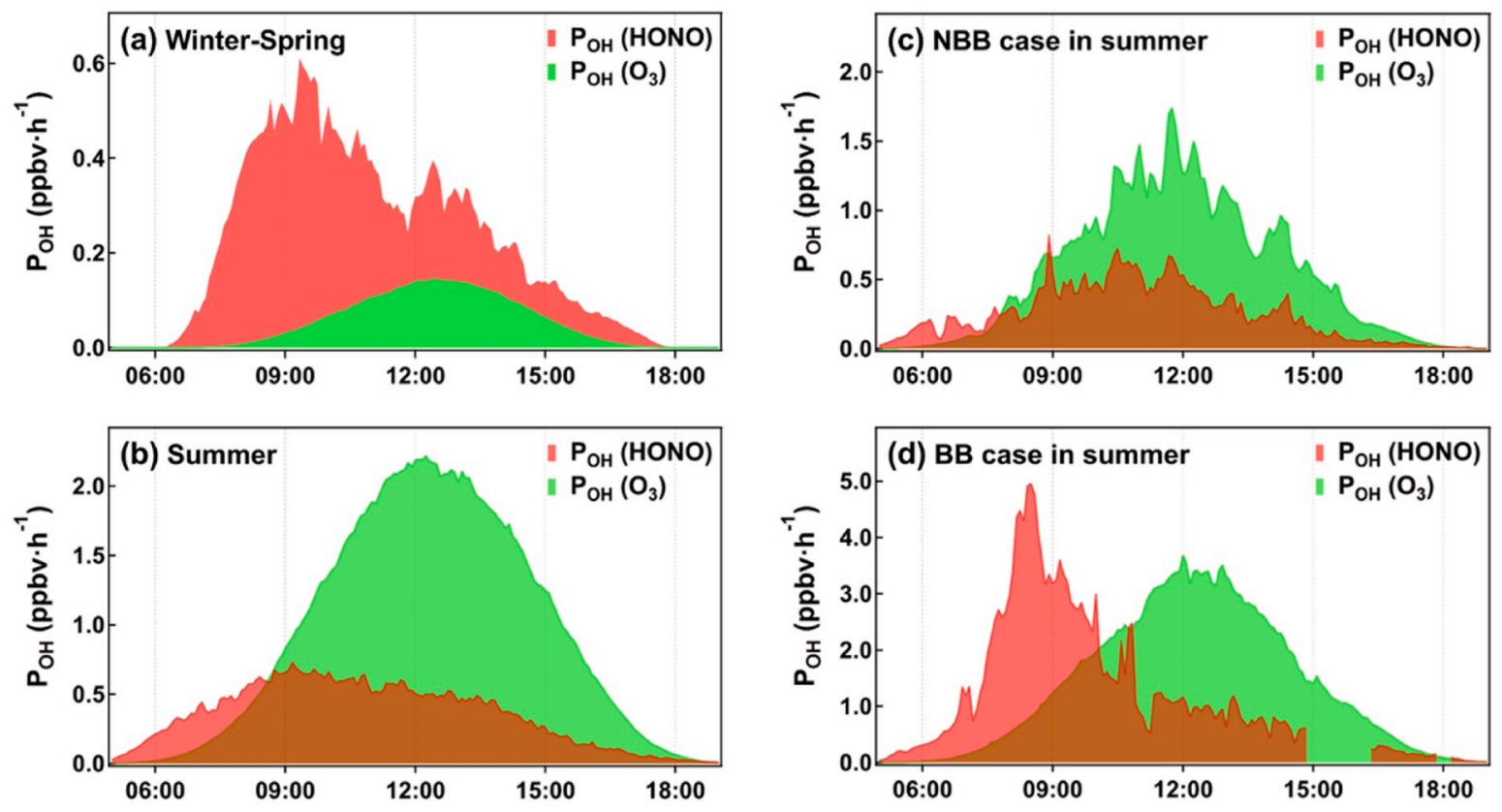

Fig. 6. Production rates of $\mathrm{OH}$ from the photolysis of $\mathrm{HONO}$ and $\mathrm{O}_{3}$ in (a) winter-spring, (b) summer, (c) the non-biomass burning (NBB) case in summer, and (d) the biomass burning (BB) case in summer. 
$\mathrm{O}\left({ }^{1} \mathrm{D}\right)+\mathrm{H}_{2} \mathrm{O} \rightarrow 2 \mathrm{OH}$

$\mathrm{O}\left({ }^{1} \mathrm{D}\right)+\mathrm{M} \rightarrow \mathrm{O}\left({ }^{3} \mathrm{P}\right)+\mathrm{M}\left(\mathrm{M}=\mathrm{N}_{2}\right.$ or $\left.\mathrm{O}_{2}\right)$

$\mathrm{P}_{\mathrm{OH}}(\mathrm{HONO})=\mathrm{j}(\mathrm{HONO})[\mathrm{HONO}]-\mathrm{k}_{\mathrm{OH}+\mathrm{HONO}}[\mathrm{HONO}][\mathrm{OH}]$

$-\mathrm{k}_{\mathrm{OH}+\mathrm{NO}}[\mathrm{NO}][\mathrm{OH}]$

$\mathrm{P}_{\mathrm{OH}}\left(\mathrm{O}_{3}\right)=\mathrm{j}\left(\mathrm{O}^{1} \mathrm{D}\right)\left[\mathrm{O}_{3}\right] \cdot \frac{2 \mathrm{k}_{\mathrm{O}\left({ }^{1} \mathrm{D}\right)+\mathrm{H}_{2} \mathrm{O}}\left[\mathrm{H}_{2} \mathrm{O}\right]}{\mathrm{k}_{\mathrm{O}\left({ }^{1} \mathrm{D}\right)+\mathrm{H}_{2} \mathrm{O}}\left[\mathrm{H}_{2} \mathrm{O}\right]+\mathrm{k}_{\mathrm{O}\left({ }^{1} \mathrm{D}\right)+\mathrm{N}_{2}}\left[\mathrm{~N}_{2}\right]+\mathrm{k}_{\mathrm{O}\left({ }^{1} \mathrm{D}\right)+\mathrm{O}_{2}}\left[\mathrm{O}_{2}\right]}$

Fig. 6(a) and (b) present the average diurnal $\mathrm{OH}$ production rates from photolysis of $\mathrm{HONO}$ and $\mathrm{O}_{3}$ in winter-spring and summer, respectively. In winter-spring, HONO photolysis made a much greater contribution to $\mathrm{OH}$ than $\mathrm{O}_{3}$ throughout the daytime, with the peak $\mathrm{P}_{\mathrm{OH}}(\mathrm{HONO})$ of $0.61 \mathrm{ppbv} \cdot \mathrm{h}^{-1}$ in the late morning and the peak $\mathrm{P}_{\mathrm{OH}}\left(\mathrm{O}_{3}\right)$ of $0.15 \mathrm{ppbv} \cdot \mathrm{h}^{-1}$ around the noon. In summer, while HONO contributed more $\mathrm{OH}$ than $\mathrm{O}_{3}$ did before the late morning with the peak $\mathrm{P}_{\mathrm{OH}}(\mathrm{HONO})$ of $0.73 \mathrm{ppbv} \cdot \mathrm{h}^{-1}, \mathrm{O}_{3}$ photolysis became the more significant $\mathrm{OH}$ source during the rest of the daytime with the peak $\mathrm{P}_{\mathrm{OH}}\left(\mathrm{O}_{3}\right)$ of $2.22 \mathrm{ppbv} \cdot \mathrm{h}^{-1}$ around the noon. On average, during the daytime of 08:00-17:00 LT, $\mathrm{P}_{\mathrm{OH}}(\mathrm{HONO})$ accounted for $78 \%$ of $\mathrm{P}_{\mathrm{OH}}\left(\mathrm{HONO}+\mathrm{O}_{3}\right)$ in winter-spring and $26 \%$ in summer. The seasonal difference in the relative contribution of $\mathrm{HONO}$ and $\mathrm{O}_{3}$ to $\mathrm{OH}$ was the combined effect of the seasonal changes in the concentrations of HONO and $\mathrm{O}_{3}$ and in the photochemistry. Specifically, HONO showed higher concentrations in winter-spring than in summer, whilst $\mathrm{O}_{3}$ showed much higher levels in summer than in winter-spring, owing to the seasonal variation of sunlight and hence photochemical processes. To sum up, HONO plays a significant role in $\mathrm{OH}$ formation and hence affects the atmospheric oxidation capacity in both seasons.

Fig. 6(c) and (d) display the diurnal OH production rates from HONO and $\mathrm{O}_{3}$ photolysis in the $\mathrm{NBB}$ case and $\mathrm{BB}$ case, respectively. Compared with the NBB case, $\mathrm{P}_{\mathrm{OH}}(\mathrm{HONO})$ in the $\mathrm{BB}$ case increased greatly, especially in the morning. $\mathrm{P}_{\mathrm{OH}}(\mathrm{HONO})$ in the $\mathrm{BB}$ case was about five times larger than that in the NBB case with a peak of $5.0 \mathrm{ppbv} \cdot \mathrm{h}^{-1}$ in the late morning, and $\mathrm{P}_{\mathrm{OH}}\left(\mathrm{O}_{3}\right)$ in the $\mathrm{BB}$ case reached the peak of $3.7 \mathrm{ppbv} \cdot \mathrm{h}^{-1}$ around noon with the average value of over two times higher than that in the NBB case. The differences of $\mathrm{P}_{\mathrm{OH}}(\mathrm{HONO})$ and $\mathrm{P}_{\mathrm{OH}}\left(\mathrm{O}_{3}\right)$ are consistent with the concentration differences of $\mathrm{HONO}$ and $\mathrm{O}_{3}$ between the two cases. In terms of relative contribution, while $\mathrm{P}_{\mathrm{OH}}(\mathrm{HONO})$ was larger than $\mathrm{P}_{\mathrm{OH}}\left(\mathrm{O}_{3}\right)$ only before 08:00 in the NBB case, $\mathrm{P}_{\mathrm{OH}}(\mathrm{HONO})$ in the $\mathrm{BB}$ case was larger than $\mathrm{P}_{\mathrm{OH}}\left(\mathrm{O}_{3}\right)$ before 10:00 and was over three times higher than $\mathrm{P}_{\mathrm{OH}}\left(\mathrm{O}_{3}\right)$ during 06:00-10:00. These results indicate the significant impacts of BB on HONO and atmospheric oxidation capacity, and $\mathrm{BB}$ should be taken into consideration in atmospheric modelling study and pollution control policy-making.

\section{Summary and conclusions}

The paper presents the HONO measured during the winter-spring and summer in 2017 at a rural coastal site in North China and demonstrates the significant seasonal variations in HONO pollution and chemistry, including the pollution characteristics, nocturnal $\mathrm{C}_{\mathrm{HONO}}$ daytime budgets, and the impacts on atmospheric oxidation capacity. More severe air pollution was observed in winter-spring than in summer, with the mean HONO mixing ratio of $0.26 \pm 0.28 \mathrm{ppbv}$ in winter-spring and $0.17 \pm 0.19 \mathrm{ppbv}$ in summer. The $\mathrm{HONO} / \mathrm{NO}_{\mathrm{x}}$ ratio in summer was about twice of that in winter-spring, and it reached a peak at noon in summer, which indicated the photo-enhanced heterogeneous formation of HONO. The mean nocturnal $\mathrm{C}_{\mathrm{HONO}}$ in summer was over twice of that in winter-spring. Budget analysis indicated a much stronger daytime $\mathrm{P}_{\text {other }}$ in summer $\left(0.14-0.56 \mathrm{ppbv} \cdot \mathrm{h}^{-1}\right)$ than in winter-spring $(0.02-0.23$ $\mathrm{ppbv} \cdot \mathrm{h}^{-1}$ ), and the enhanced photo-induced HONO formation mechanisms were suggested through correlation analysis. Photolysis of nitrate and nitric acid may be the most significant HONO sources, followed by the comparable photo-enhanced heterogeneous conversion of $\mathrm{NO}_{2}$. HONO photolysis was the major contributor to $\mathrm{OH}$ in winter-spring and also a significant $\mathrm{OH}$ source in summer. Biomass burning was found to make a significant contribution to HONO through direct HONO emission and aerosol release, which provided HONO precursors and heterogeneous reaction surface. Biomass burning affected HONO chemistry by enhancing the effects of aerosol and weakening the role of photolysis on HONO formation. Besides, HONO photolysis could be enhanced to be the major $\mathrm{OH}$ contributor in the morning in the $\mathrm{BB}$ case. Therefore, biomass burning should be taken into consideration in HONO study and in making regional pollution control policy, especially during the harvest seasons.

\section{Funding}

This work was supported by the National Natural Science Foundation of China (41675118, 91544213, and 41505111), the Hong Kong Research Grants Council (T24-504/17-N), the Shandong Provincial Natural Science Foundation for Distinguished Young Scholars (ZR2019JQ09), the Qilu Youth Talent Program of Shandong University, and the Jiangsu Collaborative Innovation Center for Climate Change.

\section{Declaration of competing interest}

The authors declare that they have no known competing financial interests or personal relationships that could have appeared to influence the work reported in this paper.

\section{CRediT authorship contribution statement}

Rongrong Gu: Formal analysis, Writing - original draft. Penggang Zheng: Investigation, Data curation. Tianshu Chen: Investigation, Data curation. Can Dong: Writing - review \& editing. Ya'nan Wang: Investigation, Methodology. Yiming Liu: Investigation, Methodology. Yuhong Liu: Investigation. Yuanyuan Luo: Investigation, Data curation. Guangxuan Han: Resources. Xinfeng Wang: Investigation. Xuehua Zhou: Investigation. Tao Wang: Supervision, Writing - review \& editing. Wenxing Wang: Supervision, Resources. Likun Xue: Conceptualization, Funding acquisition, Project administration, Writing - review \& editing.

\section{Acknowledgements}

The authors are grateful to the Yellow River Delta Ecology Research Station of Coastal Wetland of Chinese Academy of Science and its all staff for offering convenience on our field observation and accommodation, and to the NASA for offering the fire map information.

\section{Appendix A. Supplementary data}

Supplementary data to this article can be found online at https://doi. org/10.1016/j.atmosenv.2020.117429.

\section{References}

Acker, K., Febo, A., Trick, S., Perrino, C., Bruno, P., Wiesen, P., Möller, D., Wieprecht, W., Auel, R., Giusto, M., Geyer, A., Platt, U., Allegrini, I., 2006a. Nitrous acid in the urban area of Rome. Atmos. Environ. 40, 3123-3133. https://doi.org/10.1016/j. atmosenv.2006.01.028.

Acker, K., Möller, D., Wieprecht, W., Meixner, F.X., Bohn, B., Gilge, S., Plass-Dülmer, C., Berresheim, H., 2006b. Strong daytime production of $\mathrm{OH}$ from $\mathrm{HNO}_{2}$ at a rural mountain site. Geophys. Res. Lett. 33, L02809. https://doi.org/10.1029/ 2005 GL024643.

Alicke, B., Platt, U., Stutz, J., 2002. Impact of nitrous acid photolysis on the total hydroxyl radical budget during the Limitation of Oxidant Production/Pianura Padana Produzione di Ozono study in Milan. J. Geophys. Res. 107, 8196. https://doi. org/10.1029/2000JD000075. 
Atkinson, R., Baulch, D.L., Cox, R.A., Crowley, J.N., Hampson, R.F., Hynes, R.G., Jenkin, M.E., Rossi, M.J., Troe, J., 2004. Evaluated kinetic and photochemical data for atmospheric chemistry: volume I - gas phase reactions of Ox, HOx, NOx and SOx species. Atmos. Chem. Phys. 4, 1461-1738. https://doi.org/10.5194/acp-4-14612004.

Bejan, I., Abd El Aal, Y., Barnes, I., Benter, T., Bohn, B., Wiesen, P., Kleffmann, J., 2006. The photolysis of ortho-nitrophenols: a new gas phase source of HONO. Phys. Chem. Chem. Phys. 8, 2028-2035. https://doi.org/10.1039/B516590C.

Burling, I.R., Yokelson, R.J., Griffith, D.W.T., Johnson, T.J., Veres, P., Roberts, J.M., Warneke, C., Urbanski, S.P., Reardon, J., Weise, D.R., Hao, W.M., de Gouw, J., 2010. Laboratory measurements of trace gas emissions from biomass burning of fuel types from the southeastern and southwestern United States. Atmos. Chem. Phys. 10, 11115-11130. https://doi.org/10.5194/acp-10-11115-2010.

Carr, S., Heard, D.E., Blitz, M.A., 2009. Comment on "Atmospheric hydroxyl radical production from electronically excited NO2 and H2O. Science 324, 336b. https:// doi.org/10.1126/science.1166669.

Finlayson-Pitts, B.J., Pitts, J.N., 2000. Chemistry of the Upper and Lower Atmosphere. Academic Press, San Diego. http://www.sciencedirect.com/science/article/pii /B9780122570605500009.

Finlayson-Pitts, B.J., Wingen, L.M., Sumner, A.L., Syomin, D., Ramazan, K.A., 2003. The heterogeneous hydrolysis of NO2 in laboratory systems and in outdoor and indoor atmospheres: an integrated mechanism. Phys. Chem. Chem. Phys. 5, 223-242. https://doi.org/10.1039/B208564J.

Fu, X., Wang, T., Zhang, L., Li, Q., Wang, Z., Xia, M., Yun, H., Wang, W., Yu, C., Yue, D., Zhou, Y., Zheng, J., Han, R., 2019. The significant contribution of HONO to secondary pollutants during a severe winter pollution event in southern China. Atmos. Chem. Phys. 19, 1-14. https://doi.org/10.5194/acp-19-1-2019.

Gen, M., Zhang, R., Huang, D., Li, Y., Chan, C., 2019. Heterogeneous oxidation of $\mathrm{SO}_{2}$ in sulfate production during nitrate photolysis at $300 \mathrm{~nm}$ : effect of $\mathrm{pH}$, relative humidity, irradiation intensity, and the presence of organic compounds. Environ. Sci. Technol. 53 (15), 8757-8766. https://doi.org/10.1021/acs.est.9b01623, 2019.

Han, C., Yang, W., Yang, H., Xue, X., 2017. Enhanced photochemical conversion of $\mathrm{NO}_{2}$ to HONO on humic acids in the presence of benzophenone. Environ. Pollut. 231, 979-986. https://doi.org/10.1016/j.envpol.2017.08.107.

Harrison, R.M., Peak, J.D., Collins, G.M., 1996. Tropospheric cycle of nitrous acid. J. Geophys. Res.: Atmosphere 101, 14429-14439. https://doi.org/10.1029/ 96JD00341.

Heland, J., Kleffmann, J., Kurtenbach, R., Wiesen, P., 2001. A new instrument to measure gaseous nitrous acid (HONO) in the atmosphere. Environ. Sci. Technol. 35, 3207-3212. https://doi.org/10.1021/es000303t.

Kleffmann, J., Benter, T., Wiesen, P., 2004. Heterogeneous reaction of nitric acid with nitric oxide on glass surfaces under simulated atmospheric conditions. J. Phys. Chem. 108, 5793-5799. https://doi.org/10.1021/jp040184u.

Lammel, G., Cape, J.N., 1996. Nitrous acid and nitrite in the atmosphere. Chem. Soc Rev. 25, 361-369. https://doi.org/10.1039/CS9962500361.

Li, D., Xue, L., Wen, L., Wang, X., Chen, T., Mellouki, A., Chen, J., Wang, W., 2018. Characteristics and sources of nitrous acid in an urban atmosphere of northern China: results from 1-yr continuous observations. Atmos. Environ. 182, 296-306. https://doi.org/10.1016/j.atmosenv.2018.03.033.

Li, S., Matthews, J., Sinha, A., 2008. Atmospheric hydroxyl radical production from electronically excited NO2 and H2O. Science 319, 1657-1660. https://doi.org/ 10.1126/science.1151443.

Li, X., Brauers, T., Häseler, R., Bohn, B., Fuchs, H., Hofzumahaus, A., Holland, F., Lou, S. Lu, K.D., Rohrer, F., Hu, M., Zeng, L.M., Zhang, Y.H., Garland, R.M., Su, H., Nowak, A., Wiedensohler, A., Takegawa, N., Shao, M., Wahner, A., 2012. Exploring the atmospheric chemistry of nitrous acid (HONO) at a rural site in Southern China. Atmos. Chem. Phys. 12, 1497-1513. https://doi.org/10.5194/acp-12-1497-2012.

Liang, Y., Zha, Q., Wang, W., Cui, L., Lui, K.H., Ho, K.F., Wang, Z., Lee, S.-C., Wang, T. 2017. Revisiting nitrous acid (HONO) emission from on-road vehicles: a tunnel study with a mixed fleet. J. Air Waste Manag. Assoc. 67, 797-805. https://doi.org/ 10.1080/10962247.2017.1293573.

Liu, Y., Lu, K., Ma, Y., Yang, X., Zhang, W., Wu, Y., Peng, J., Shuai, S., Hu, M., Zhang, Y., 2017. Direct emission of nitrous acid (HONO) from gasoline cars in China determined by vehicle chassis dynamometer experiments. Atmos. Environ. 169, 89-96. https://doi.org/10.1016/j.atmosenv.2017.07.019.

Liu, Y., Nie, W., Xu, Z., Wang, T., Wang, R., Li, Y., Wang, L., Chi, X., Ding, A., 2019. Contributions of different sources to nitrous acid (HONO) at the SORPES station in eastern China: results from one-year continuous observation. Atmos. Chem. Phys. Discuss. 1-47. https://doi.org/10.5194/acp-2019-219.

Meusel, H., Kuhn, U., Reiffs, A., Mallik, C., Harder, H., Martinez, M., Schuladen, J., Bohn, B., Parchatka, U., Crowley, J.N., Fischer, H., Tomsche, L., Novelli, A., Hoffmann, T., Janssen, R.H.H., Hartogensis, O., Pikridas, M., Vrekoussis, M., Bourtsoukidis, E., Weber, B., Lelieveld, J., Williams, J., Pöschl, U., Cheng, Y., Su, H., 2016. Daytime formation of nitrous acid at a coastal remote site in Cyprus indicating a common ground source of atmospheric HONO and NO. Atmos. Chem. Phys. 16, 14475-14493. https://doi.org/10.5194/acp-16-14475-2016.

Monge, M.E., D’Anna, B., Mazri, L., Giroir-Fendler, A., Ammann, M., Donaldson, D.J., George, C., 2010. Light changes the atmospheric reactivity of soot. Proc. Natl. Acad. Sci. Unit. States Am. 107, 6605-6609. https://doi.org/10.1073/pnas.0908341107.

Nie, W., Ding, A.J., Xie, Y.N., Xu, Z., Mao, H., Kerminen, V.M., Zheng, L.F., Qi, X.M., Huang, X., Yang, X.Q., Sun, J.N., Herrmann, E., Petäjä, T., Kulmala, M., Fu, C.B., 2015. Influence of biomass burning plumes on HONO chemistry in eastern China. Atmos. Chem. Phys. 15, 1147-1159. https://doi.org/10.5194/acp-15-1147-2015.

Oswald, R., Behrendt, T., Ermel, M., Wu, D., Su, H., Cheng, Y., Breuninger, C. Moravek, A., Mougin, E., Delon, C., Loubet, B., Pommerening-Röser, A., Sörgel, M., Pöschl, U., Hoffmann, T., Andreae, M.O., Meixner, F.X., Trebs, I., 2013. HONO emissions from soil bacteria as a major source of atmospheric reactive nitrogen. Science 341, 1233-1235, https://doi.org/10.1126/science.1242266.

Ren, X., Harder, H., Martinez, M., Lesher, R.L., Oliger, A., Simpas, J.B., Brune, W.H., Schwab, J.J., Demerjian, K.L., He, Y., Zhou, X., Gao, H., 2003. OH and $\mathrm{HO}_{2}$ chemistry in the urban atmosphere of New York City. Atmos. Environ. 37, 3639-3651. https://doi.org/10.1016/S1352-2310(03)00459-X.

Rohrer, F., Berresheim, H., 2006. Strong correlation between levels of tropospheric hydroxyl radicals and solar ultraviolet radiation. Nature 442, 184-187. https://doi. org/10.1038/nature04924.

Sörgel, M., Regelin, E., Bozem, H., Diesch, J.M., Drewnick, F., Fischer, H., Harder, H., Held, A., Hosaynali-Beygi, Z., Martinez, M., Zetzsch, C., 2011. Quantification of the unknown HONO daytime source and its relation to $\mathrm{NO}_{2}$. Atmos. Chem. Phys. 11, 10433-10447. https://doi.org/10.5194/acp-11-10433-2011.

Sakamaki, F., Hatakeyama, S., Akimoto, H., 1983. Formation of nitrous acid and nitric oxide in the heterogeneous dark reaction of nitrogen dioxide and water vapor in a smog chamber. Int. J. Chem. Kinet. 15, 1013-1029. https://doi.org/10.1002/ kin. 550151006.

Saliba, N.A., Yang, H., Finlayson-Pitts, B.J., 2001. Reaction of gaseous nitric oxide with nitric acid on silica surfaces in the presence of water at room temperature. J. Phys. Chem. 105, 10339-10346. https://doi.org/10.1021/jp012330r.

Stemmler, K., Ammann, M., Donders, C., Kleffmann, J., George, C., 2006. Photosensitized reduction of nitrogen dioxide on humic acid as a source of nitrous acid. Nature 440, 195-198. https://doi.org/10.1038/nature04603.

Su, H., Cheng, Y.F., Cheng, P., Zhang, Y.H., Dong, S.F., Zeng, L.M., Wang, X.S., Slanina, J., Shao, M., Wiedensohler, A., 2008a. Observation of nighttime nitrous acid (HONO) formation at a non-urban site during PRIDE-PRD2004 in China. Atmos. Environ. 42, 6219-6232. https://doi.org/10.1016/j.atmosenv.2008.04.006.

Su, H., Cheng, Y.F., Shao, M., Gao, D.F., Yu, Z.Y., Zeng, L.M., Slanina, J., Zhang, Y.H., Wiedensohler, A., 2008b. Nitrous acid (HONO) and its daytime sources at a rural site during the 2004 PRIDE-PRD experiment in China. J. Geophys. Res.: Atmosphere 113, D14312. https://doi.org/10.1029/2007JD009060.

Wang, J., Zhang, X., Guo, J., Wang, Z., Zhang, M., 2017. Observation of nitrous acid (HONO) in Beijing, China: seasonal variation, nocturnal formation and daytime budget. Sci. Total Environ. 587-588, 350-359. https://doi.org/10.1016/j. scitotenv.2017.02.159.

Wang, S., Zhou, R., Zhao, H., Wang, Z., Chen, L., Zhou, B., 2013. Long-term observation of atmospheric nitrous acid (HONO) and its implication to local NO2 levels in Shanghai, China. Atmos. Environ. 77, 718-724. https://doi.org/10.1016/j. atmosenv.2013.05.071.

Wen, L., Chen, T., Zheng, P., Wu, L., Wang, X., Mellouki, A., Xue, L., Wang, W., 2019. Nitrous acid in marine boundary layer over eastern Bohai Sea, China: Characteristics, sources, and implications. Sci. Total Environ. 670, 282-291. https:// doi.org/10.1016/j.scitotenv.2019.03.225.

Xu, Z., Wang, T., Wu, J., Xue, L., Chan, J., Zha, Q., Zhou, S., Louie, P.K.K., Luk, C.W.Y., 2015. Nitrous acid (HONO) in a polluted subtropical atmosphere: seasonal variability, direct vehicle emissions and heterogeneous production at ground surface. Atmos. Environ. 106, 100-109. https://doi.org/10.1016/j. atmosenv.2015.01.061.

Xue, L., Gu, R., Wang, T., Wang, X., Saunders, S., Blake, D., Louie, P.K.K., Luk, C.W.Y., Simpson, I., Xu, Z., Wang, Z., Gao, Y., Lee, S., Mellouki, A., Wang, W., 2016. Oxidative capacity and radical chemistry in the polluted atmosphere of Hong Kong and Pearl River Delta region: analysis of a severe photochemical smog episode. Atmos. Chem. Phys. 16, 9891-9903. https://doi.org/10.5194/acp-16-9891-2016.

Yang, Q., Su, H., Li, X., Cheng, Y., Lu, K., Cheng, P., Gu, J., Guo, S., Hu, M., Zeng, L., Zhu, T., Zhang, Y., 2014. Daytime HONO formation in the suburban area of the megacity Beijing, China. Sci. China Chem. 57, 1032-1042. https://doi.org/10.1007/ s11426-013-5044-0.

Yang, W., Han, C., Yang, H., Xue, X., 2018. Significant HONO formation by the photolysis of nitrates in the presence of humic acids. Environ. Pollut. 243, 679-686. https:// doi.org/10.1016/j.envpol.2018.09.039.

Ye, C., Gao, H., Zhang, N., Zhou, X., 2016a. Photolysis of nitric acid and nitrate on natural and artificial surfaces. Environ. Sci. Technol. 50, 3530-3536. https://doi org/10.1021/acs.est.5b05032.

Ye, C., Zhang, N., Gao, H., Zhou, X., 2017. Photolysis of particulate nitrate as a source of HONO and NOx. Environ. Sci. Technol. 51, 6849-6856. https://doi.org/10.1021 acs.est.7b00387.

Ye, C., Zhou, X., Pu, D., Stutz, J., Festa, J., Spolaor, M., Cantrell, C., Mauldin, R.L., Weinheimer, A., Haggerty, J., 2015. Comment on "Missing gas-phase source of HONO inferred from Zeppelin measurements in the troposphere.". Science 348. https://doi.org/10.1126/science.aaa1992, 1326-1326.

Ye, C., Zhou, X., Pu, D., Stutz, J., Festa, J., Spolaor, M., Tsai, C., Cantrell, C., Mauldin III, R.L., Campos, T., Weinheimer, A., Hornbrook, R.S., Apel, E.C., Guenther, A., Kaser, L., Yuan, B., Karl, T., Haggerty, J., Hall, S., Ullmann, K., Smith, J.N., Ortega, J., Knote, C., 2016b. Rapid cycling of reactive nitrogen in the marine boundary layer. Nature 532, 489-491. https://doi.org/10.1038/ nature17195.

Yin, L., Du, P., Zhang, M., Liu, M., Xu, T., Song, Y., 2019. Estimation of emissions from biomass burning in China (2003-2017) based on MODIS fire radiative energy data. Biogeosciences 16, 1629-1640. https://doi.org/10.5194/bg-16-1629-2019.

Yokelson, R.J., Crounse, J.D., DeCarlo, P.F., Karl, T., Urbanski, S., Atlas, E., Campos, T., Shinozuka, Y., Kapustin, V., Clarke, A.D., Weinheimer, A., Knapp, D.J., Montzka, D. D., Holloway, J., Weibring, P., Flocke, F., Zheng, W., Toohey, D., Wennberg, P.O., Wiedinmyer, C., Mauldin, L., Fried, A., Richter, D., Walega, J., Jimenez, J.L., Adachi, K., Buseck, P.R., Hall, S.R., Shetter, R., 2009. Emissions from biomas burning in the Yucatan. Atmos. Chem. Phys. 9, 5785-5812. https://doi.org/ 10.5194/acp-9-5785-2009. 
Yu, Y., Galle, B., Panday, A., Hodson, E., Prinn, R., Wang, S., 2009. Observations of high rates of $\mathrm{NO}_{2}$ - $\mathrm{HONO}$ conversion in the nocturnal atmospheric boundary layer in Kathmandu, Nepal. Atmos. Chem. Phys. 9, 541-546. https://doi.org/10.5194/acp-96401-2009.

Yun, H., Wang, Z., Zha, Q., Wang, W., Xue, L., Zhang, L., Li, Q., Cui, L., Lee, S., Poon, S.C N., Wang, T., 2017. Nitrous acid in a street canyon environment: sources and contributions to local oxidation capacity. Atmos. Environ. 167, 223-234. https:// doi.org/10.1016/j.atmosenv.2017.08.018.

Zhang, B., Tao, F.-M., 2010. Direct homogeneous nucleation of $\mathrm{NO}_{2}, \mathrm{H}_{2} \mathrm{O}$, and $\mathrm{NH}_{3}$ for the production of ammonium nitrate particles and HONO gas. Chem. Phys. Lett. 489, 143-147. https://doi.org/10.1016/j.cplett.2010.02.059.

Zhang, L., Wang, T., Zhang, Q., Zheng, J., Xu, Z., Lv, M., 2016. Potential sources of nitrous acid (HONO) and their impacts on ozone: a WRF-Chem study in a polluted subtropical region. J. Geophys. Res.: Atmosphere 121, 3645-3662. https://doi.org/ 10.1002/2015JD024468.
Zhang, Y., Sun, J., Zheng, P., Chen, T., Liu, Y., Han, G., Simpson, I.J., Wang, X., Blake, D. R., Li, Z., Yang, X., Qi, Y., Wang, Q., Wang, W., Xue, L., 2019. Observations of $C_{1}-C_{5}$ alkyl nitrates in the Yellow River Delta, northern China: effects of biomass burning and oil field emissions. Sci. Total Environ. 656, 129-139. https://doi.org/10.1016/j. scitotenv. 2018.11.208.

Zheng, P., Chen, T., Dong, C., Liu, Y., Li, H., Han, G., Sun, J., Wu, L., Gao, X., Wang, X., Qi, Y., Zhang, Q., Wang, W., Xue, L., 2019. Characteristics and sources of halogenated hydrocarbons in the Yellow River Delta region, northern China. Atmos. Res. 225, 70-80. https://doi.org/10.1016/j.atmosres.2019.03.039.

Zhou, X., Gao, H., He, Y., Huang, G., Bertman, S.B., Civerolo, K., Schwab, J., 2003. Nitric acid photolysis on surfaces in low-NOx environments: significant atmospheric implications. Geophys. Res. Lett. 30, 2217. https://doi.org/10.1029/ 2003GL018620. 